\title{
ЛОГІКА ВИЗНАЧЕННЯ ЗДОРОВ'Я ІНДИВІДА ТА ПОПУЛЯЦІї. ЧАСТИНА 2. ЕВОЛЮЦІЙНА МЕДИЦИНА. СИСТЕМНО-БІОЛОГІЧНІ ТА ІНФОРМАЦІЙНІ АСПЕКТИ ЗДОРОВ'Я ЛЮДИНИ
}

\author{
О. П. Мінцер, А. М. Новік ${ }^{1}$ \\ Національний університет охорони здоров'я України імені П. Л. Шупика \\ ${ }^{1} T O B$ «НВК «Екофрарм»»
}

\begin{abstract}
Представлено бачення інтеграції ключових питань еволюційної медицини та валеології. Визначено шляхи синтезу класичних уявлень про здоров'я індивіду з концептами еволюційної медицини та інструментарієм відображення проблем індивідуального здоров'я за допомогою інорормаційних технологій. У результаті дослідження виявлено, що еволюційна медицина зміщує акцент із дихотомічного розгляду здоров'я та захворювань на більш контекстуальний розгляд. Підкреслюється необхідність трансдисциплінарного синтезу дисциплін про здоров'я людини. Створено віртуальну сервісну програму відслідковування стану здоров'я людини, що дає можливість протягом усього її життя реєструвати всі зміни стану здоров'я та сприяти своєчасній корекції патологічних змін. Платорорма $є$ реальним утіленням загальновідомої істини - попередити хворобу простіше, ніж її вилікувати. Питання, чи $є$ еволюційна медицина фрундаментальною наукою - важливим світоглядом узагальнення проблем здоров'я та захворювань - залишається. Застосування еволюційної перспективи до клінічної практики хоча не впливає на повсякденні терапевтичні рішення, але може призвести до нових клінічних стратегій. Тим не менш, клінічна медицина та громадська охорона здоров'я насамперед зосереджені на етіології, профрілактиці та лікуванні захворювань, а вже потім на зміцненні здоров'я. Ця невідповідність і $є$ причиною того, що лікарі не завжди правильно розставляють акценти в різних фрормах своєї діяльності.
\end{abstract}

Ключові слова: еволюційна медицина, системна біомедицина, концепція «еvo-devo», індивідуальне здоров'я, регуляція біологічних процесів старіння та довголіття, інфрормаційні технології.

\section{THE LOGIC OF DETERMINING THE HEALTH OF THE INDIVIDUAL AND THE POPULATION. PART 2. EVOLUTIONARY MEDICINE. SYSTEM-BIOLOGICAL AND INFORMATIONAL ASPECTS OF HUMAN HEALTH}

\author{
O. P. Mintser, A. M. Novyk ${ }^{1}$
}

\author{
Shupyk National Healthcare University of Ukraine \\ ${ }^{1}$ Research and Production Company Ecopharm, Ltd.
}

\begin{abstract}
Background. The issues of integration of key issues of evolutionary medicine and valeology are considered. The aim of the research is to determine the ways of synthesis of classical ideas about the health of the individual with the concepts of evolutionary medicine and tools for reflecting the problems of individual health with the help of information technology.

Materials and methods. Results. Evolutionary medicine shifts the emphasis from the dichotomous consideration of health and disease to a more contextual consideration. The need for a transdisciplinary synthesis of human health disciplines is emphasized. A virtual service program for monitoring the state of human health has been created, which makes it possible to register all changes in the state of health throughout his life and to promote the timely correction of pathological changes. The platform is the real embodiment of the well-known truth - it is easier to prevent a disease than to cure it. The question of whether evolutionary medicine is a fundamental science - an important worldview of generalizing health problems and diseases - remains.

Conclusions. Applying an evolutionary perspective to clinical practice, while not influencing everyday therapeutic decisions, can lead to new clinical strategies. However, clinical medicine and public health focus primarily on the etiology, prevention and treatment of disease, and only then on health promotion. This discrepancy is the reason that doctors do not always place the right emphasis in different forms of their activities.
\end{abstract}

Key words: evolutionary medicine, systems biomedicine, the «evo-devo» concept, individual health, regulation of the biological processes of aging and longevity, information technology. 


\title{
ЛОГИКА ОПРЕДЕЛЕНИЯ ЗДОРОВЬЯ ИНДИВИДУУМА И ПОПУЛЯЦИИ. ЧАСТЬ 2. ЭВОЛЮЦИОННАЯ МЕДИЦИНА. СИСТЕМНО-БИОЛОГИЧЕСКИЕ И ИНФОРМАЦИОННЫЕ АСПЕКТЫ ЗДОРОВЬЯ ЧЕЛОВЕКА
}

\author{
О. П. Минцер, А. М. Новик ${ }^{1}$ \\ Национальный университет здравоохранения Украины имени П. Л. Шупика \\ ${ }^{1} \mathrm{OOO}$ «НПК «Экофрарм»»
}

\begin{abstract}
Представлено видение интеграции ключевых вопросов эволюционной медицины и валеологии. Определены пути синтеза классических представлений о здоровье индивида с концептами эволюционной медицины и инструментарием отражения проблем индивидуального здоровья при помощи инсормационных технологий. В результате исследования обнаружено, что эволюционная медицина смещает акцент с дихотомического рассмотрения здоровья и заболеваний на более контекстуальное рассмотрение. Подчеркивается необходимость трансдисциплинарного синтеза дисциплин о здоровье человека. Создана виртуальная сервисная программа отслеживания состояния здоровья человека, позволяющая в течение всей его жизни регистрировать все изменения состояния здоровья и способствовать своевременной коррекции патологических изменений. Платорорма является реальным воплощением общеизвестной истины — предотвратить болезнь проще, чем ее вылечить. Вопрос, является ли эволюционная медицина фундаментальной наукой - важным мировоззрением обобщения проблем здоровья и заболеваний - остается. Применение эволюционной перспективы к клинической практике не влияет на повседневные терапевтические решения, но может привести к новым клиническим стратегиям. Тем не менее, клиническая медицина и общественное здравоохранение, прежде всего, сосредоточены на этиологии, профилактике и лечении заболеваний, а уже потом на укреплении здоровья. Это несоответствие и есть причина того, что врачи не всегда правильно расставляют акценты в разных формах своей деятельности.
\end{abstract}

Ключевые слова: эволюционная медицина, системная биомедицина, концепция «еvo-devo», индивидуальное здоровье, регуляция биологических процессов старения и долголетия, инорормационные технологии.

Вступ. Еволюційна медицина за сучасними уявленнями - додаток сучасної еволюційної теорії до розуміння здоров’я. Вона зосереджується на питанні, чому еволюція сформувала ці механізми таким чином, що вони можуть зробити нас сприйнятливими до виникнення захворювання. Останнє добре розуміється виходячи з двох класичних питань: функціоналісти запитують про структурні взаємодії та яким чином працює механізм. Спеціалісти еволюційного напряму висловлюють запитання, чому організми є такими, якими вони є. Еволюційний підхід призвів до важливих досягнень у сучасному розумінні виникнення онкологічних захворювань, аутоімунних захворювань тощо. Взагалі, людські хвороби та розлади функціонального стану організму мають не тільки еволюційні причини, а також безпосередні, механічні [58]. Еволюційні причини захворювання включають еволюційну спадщину (що вступає у взаємодію 3 процесами адаптації та дезадаптації), невідповідність сучасним умовам існування (що може призвести до дезадаптації через розбіжність між фенотипом і середовищем), генетичні конфлікти, що створюють нові можливості для дезадаптації. Комплексний аналіз безпосередніх і кінцевих причин захворювання може поглибити розуміння як етіології захворювання, так і еволюційних процесів [58].
У своїх теоретичних та експериментальних складових проблема еволюції за своєю значимістю (масштабністю) стоїть в одному ряду з такими найважливішими медико-біологічними проблемами, як проблема здоров'я, старіння, ракової трансформації, морфогенезу, адаптації, принципів роботи людського мозку та інших [10].

Зауважимо, дисципліна, що отримала назву «еволюційна медицина», сформувалася лише в останні десятиліття. Публікація «The Dawn of Darwinian Medicine» [132] у 1991 році стала першою значною спробою помістити хвороби людини в рамки еволюційної думки. 3 того часу концепції постійно уточнювали. В 30-х і 40-х роках XX століття запропоновано синтетичну теорію еволюції, що об’єднала ідею дарвінівського природного відбору із законами спадковості та даними популяційної генетики. Й у подальшому еволюційній медицині присвячувалась велика увага в різних систематичних оглядах і публікаціях [58, 91]. Нещодавно Американська асоціація медичних коледжів висловила думку, що еволюційна наука має бути одним із основних компонентів домедичного курсу (ААМС — Комітет Наукового фонду НHМI для майбутніх лікарів [13]).

Вибух знань про геном людини дозволив провести еволюційний аналіз на такому рівні, що раніше був неможливим. Цей аналіз сприяв вирішенню 
фундаментальних еволюційних питань, таких як: наше походження; шляхи міграції нашого виду по всьому світу; виборчий тиск, що діє на наш вид; ризики захворювань $[17,26]$. 3'явилися уніфікований дескрипторний словник концептів еволюційної медицини [63].

Однак головна проблема полягає у винятковій здатності людей глибоко змінювати навколишнє середовище, склад свого раціону харчування та соціальну структуру своїх товариств. Давно визнано, зокрема в рамках теорії побудови ніш та коеволюційної теорії генної культури, що культурні практики можуть створювати сильний тиск відбору. Сьогодні як ніколи за весь попередній період розвитку людства необхідно провести велику міждисциплінарну та трансдисциплінарну роботу, що поєднує генетику, еволюційну біологію, антропологію, археологію та медицину для з'ясування основних факторів ризику і конфаундерів із метою розроблення математичних моделей у стратегії прогнозування про еволюційний вплив сучасних культурних факторів [77]. Підкреслимо, що відсутність навиків вироблення метазнання (філософія, моделювання, логіка, системологія) та користування ним у багатьох дослідників викликає огульне ігнорування необхідності їх застосування, низький рівень ерудованості в суміжних галузях біології та інших науках сильно ускладнює використання методу аналогій і використання ідей еволюційної медицини [10].

Мета дослідження: визначити шляхи синтезу класичних уявлень про здоров'я індивіду з концептами еволюційної медицини та інструментарієм відображення проблем індивідуального здоров'я за допомогою інформаційних технологій.

Результати та їх обговорення. У розпорядженні еволюційної медицини є винятковий набір теоретичних підходів і методів дослідження. Один із підходів, що досі користувався найбільшою популярністю, грунтується на інтеграції генетики ризику захворювань із вивченням еволюції людини [39]. Виникнення та розвиток еволюційної біології розвитку (англ. evolutionary developmental biology, evo-devo) дозволили, порівнюючи онтогенез різних організмів, установити родинні зв'язки між ними та розкрити розвиток онтогенетичних процесів у ході еволюції. же зараз концепція «еvo-devo» змінює процеси індивідуального розвитку, створюючи нові структури на основі старих генних мереж або зберігаючи схожі програми розвитку в безлічі різних організмів [36].

Області evo-devo, такі як теорія історії життя, надають ще одну важливу концептуальну основу для вирішення питань про здоров'я та захворювання. Вона виходить із розуміння того, що вплив навколишнього середовища в ранньому віці розвитку людини може адаптивно змінити траєкторію розвитку плода, щоб вплинути на риси в пізнішому житті за допомогою пластичності розвитку та молекулярної епігенетики. Останні дані підтверджують роль епігенетичного наслідування [61]. Невеликі некодуючі РНК i, можливо, інші форми епігенетичних міток явно можуть протягом декількох поколінь дозволити процесам біологічної спадковості виходити за межі фіксованих геномних варіацій [107].

Принципи еволюційної медицини. Останні узагальнюючі дослідження, що використовували метод Дельфі, дозволили виділити 14 основних принципів еволюційної медицини, що були розподілені на п'ять загальних категорій: формулювання питання, еволюція I та II (при цьому II передбачає більш високий рівень складності), еволюційні компроміси, причини вразливості та культура. Не маючи можливості та потреби аналізувати всі принципові підходи еволюційної медицини, зупинимося лише на основних, що стосуються проблем здоров'я.

Перший і основний принцип полягає в тому, що відбір не сприяє зміцненню здоров'я чи довголіттю, а скоріше підтримує фізичний стан здоров'я [36]. Водночас поняття фізичного стану досить складне, оскільки тісно пов'язано з віком, генетичними факторами тощо. У багатьох країнах спостерігається процес старіння суспільства, збільшення середньої тривалості життя. Відповідно дія демографічних прогнозів старіння населення продовжується [19, 49]. Ряд факторів впливають на довгострокову очікувану тривалість життя. Серед них найважливішими $є$ сприятливі - 3 погляду здоров’я - зміни довкілля, краща якість життя, висока якість медичного обслуговування та соціальних послуг. Соціальний вимір якості життя в похилому віці складається з низки питань стосовно соціально-економічної, медико-біологічної і психологічної сфер, що вимагають міждисциплінарних 
досліджень із погляду біопсихосоціального підходу [38]. Для окремих людей ключовим, очевидно, стає ефективність організму [128], що визначає суб'єктивне «відчуття тіла» чи самооцінювання здоров’я. Зазвичай це пов’язано з таким рівнем фізичної підготовки, що дозволяє автономно та незалежно функціонувати в різних сферах життя. Останнє відноситься як до самообслуговування, функціонування у сім'ї, так і функціонування в суспільстві. Фізична підготовка пов'язана з активністю, основою якої є достатній рівень фізичної та рухової незалежності [23]. Взаємодії між фізичною активністю та фізичною підготовкою, а також між фізичною активністю та здоров'ям стали предметом численних досліджень [23, 62].

Повернемось до фізичного стану здоров'я. Показано, що на фізичну форму насамперед впливають особливості життєвого анамнезу, а також зовнішні та внутрішні фактори, які впливають на захворюваність і смертність особливо до репродуктивного віку. Наприклад, наслідком змінного початку репродуктивного періоду є антагоністична плейотропія (англ. antagonistic pleiotropy) — теорія, що описує один із механізмів виникнення старіння з еволюційного погляду. Суворо кажучи, термін «антагоністична плейотропія» означає приклад кількох різних фенотипічних ефектів одного гену, в якому фіксуються не просто різні, а протилежні ефекти. Однак сьогодні цей термін використовується і для найменування ідеї або моделі, запропонованої ще в 1957 році Джорджем Вільямсом [131], також відомої під жартівливою назвою «теорія «оплати потім»». Відповідно до цієї теорії, в організмі повинні існувати плейотропні гени, що мають різний ефект на виживання організмів протягом різних періодів життя. Зокрема, запропоновані Вільямсом плейотропні гени мали пояснити процес старіння. Такі гени підтримуються в популяції, найімовірніше, завдяки їхньому позитивному впливу на розмноження в молодому віці, попри їх негативні ефекти в пізньому віці, до якого доживає незначна частина популяції. Ефект цих генів у пізньому житті й буде процесом старіння, незалежно від того, чи викликають вони старіння, чи тільки не зупиняють процес ушкоджень, спричинений іншими факторами.

В роботі [58] наведено такий приклад. Ген, що підвищує фіксацію кальцію в кістках, має позитивний ефект у молодому віці, оскільки знижує ризик переломів. Але він же має негативний ефект у літньому віці через підвищення ризику остеоартриту внаслідок надмірної кальцифікації суглобів. У природних умовах такий ген фактично не мав би негативного ефекту, оскільки більшість тварин загинула задовго до появи негативного впливу. Отже, цей негативний ефект стає важливим, лише якщо біологічні істоти живуть у захищених умовах, що може мати важливе значення для пояснення закономірностей розвитку захворювань у тому сенсі, що механізми, які еволюціонували для захисту людини до та під час розмноження, можуть бути замінені на несприятливі наслідки зниження здатності до регенерації або відновлення в середньому та похилому віці.

У більшості популяцій довголіття на сьогодні значно перевищує тривалість життя представників нашого виду навіть останнім часом: наприклад, очікувана тривалість життя при народженні для жінок у дореволюційній Франції становила близько 35 років, але сьогодні вона більш ніж подвоїлася [51]. Структура захворюваності частково відбиває збільшення частки населення, яке досягає більшої тривалості життя. Наприклад, багато видів раку просто демонструють прогресуюче збільшення захворюваності з віком, тому підвищення ризику розвитку раку значною мірою пояснюється довшою тривалістю життя внаслідок удосконалення громадської охорони здоров'я та більш гігієнічних умов (і меншою мірою - покращення медичного обслуговування). Водночас представляється можливим, що завжди існувала субпопуляція, яка доживала до середнього віку.

Старіння тривалий час було темою розгляду в еволюційній теорії, починаючи з введення вже згаданої концепції антагоністичної плейотропії і закінчуючи ії розвитком у гіпотезах ощадливого генотипу [90] та одноразової соми [67]. Показано, що старіння у соціальних видів залежить від передавання інформації між поколіннями, яке є вкладенням «ресурсів» у кожне покоління потомства [80]. Нещодавнє дослідження показало, що здатність людини передавати капітал - від енергії до знань - із покоління в покоління у поєднанні 3 накопиченням знань протягом усього життя можливо було рушійною силою відбору на довголіття [62]. 
Другий важливий принцип еволюційної медицини полягає в тому, що життя в рамках власного життєвого циклу не викликає хвороби (за винятком дії деяких окремих дефектів генів), але скоріше впливає на нашу сприйнятливість до захворінь у певних умовах. Тому, хоча традиційно медицина зазвичай використовує дихотомічні категорії (здоров’я та хвороба, норма та патологія), необхідна зовсім інша філософія. Еволюційна медицина зміщує акцент із дихотомічного розгляду (здоров'я та захворіння) на більш контекстуальний. Екстраординарний потенціал медицини людини для визначення фенотипу, генотипу та епігенотипу особи дозволяє аналізувати перебіг життя таким чином, що може бути неможливим у інших видів.

Класичним прикладом, що розглядається в багатьох дослідженнях, $є$ непереносимість лактози. До неоліту дорослим людям не потрібно було перетравлювати лактозу для харчування, проте з появою молочного тваринництва на Близькому Сході близько 9000 років тому здатність поглинати лактозу почала забезпечувати харчову перевагу [35]. Ген лактази експресується в кишечнику немовляти, але перестає експресуватися після відлучення від грудей, ймовірно тому, що при його підтримці не було селективної переваги i, можливо, при цьому були енергетичні або інші витрати. Мутації у промоторі гену лактази дозволяють його експресії зберігатися протягом усього життя. Виборча перевага, що надається цією мутацією, призвела до швидкого зростання популяції, що, зі свого боку, завдало сильний міграційний тиск, котрий спричинив швидке поширення мутації серед європейського населення. Традиційно медицина говорила про «синдром непереносимості лактози», що часто позначали як захворювання, але доречність цієї класифікації має бути поставлена під сумнів, ураховуючи, що 70 \% населення світу не толерантні до лактози та $є$ «нормальними» у контексті середовища, вільного від лактози. Іншими словами, адаптація та дезадаптація залежать від середовища, в якому знаходиться людина.

Висловлене підводить нас до третього основного еволюційного принципу. Люди тепер живуть зовсім по-іншому та в іншому середовищі. Більшість змін відбулися останні кілька сотень або тисяч років, залежно від чисельності населення, та швидкість змін довкілля кидає виклик еволюції біології популяції. Це виявило межі адаптаційних можливостей, що розвиваються, обмеження та обумовлену ними сприйнятливість до захворювань. Єдина концепція «середовища еволюційної адаптації», що була розроблена та популяризована в рамках еволюційної психології, уже давно змінилася визнанням того, що люди епохи палеоліту жили в широкому діапазоні середовищ [58]. Але через обмеження на відбір, повільність еволюційних процесів між поколіннями та стримуючу роль пластичності розвитку (що перешкоджає виборчим змінам), ці швидкі зміни навколишнього середовища та вплив еволюційно нових середовищ, зазвичай людського походження, можуть призвести до порушень з боку здоров’я.

Роль демографічних факторів. Існує безліч прикладів про вплив демографічних факторів на константи здоров'я та поширення захворювань. Наприклад, у розподілі груп крові в американських індіанців переважає група крові 0 [54]. Або сучасне фінське населення, яке зіткнулося з вузьким місцем під час міграції на північ через Фінську затоку, - це дуже однорідна популяція, яка демонструє виразну картину захворювань у порівнянні з рештою Європи, наприклад схильність до багатьох рідкісних генетичних захворювань, але також набагато меншу схильність до розвитку деяких інших захворювань, таких як муковісцидоз [97]. Аналогічна ситуація спостерігається у французьких канадців [99].

Проте більшість цієї дослідницької програми вимагатиме значно тіснішої інтеграції з іншими областями сучасних еволюційних досліджень, ніж це було досягнуто на сьогодні. Не менш важливо і те, що еволюційна медицина потребує кращої інтеграції з іншими галузями медицини. Нинішній проблемний статус еволюційної медицини в рамках сукупності медичних навчальних і дослідницьких дисциплін виходить із їі зовсім іншої перспективи, що наголошує на кінцевих, а не безпосередніх поясненнях. Тим не менш, ця перспектива, в результаті, забезпечує лікарю повніше розуміння пацієнта, а також глибше розуміння екології людини, людських відмінностей та історії життя. Це привнесе інший світогляд і спосіб мислення в медицину та громадську охорону здоров'я.

Системна біологія старіння: моделювання молекулярних механізмів розвитку вікових 
захворювань. Системна біологія - багатопрофільна галузь, що спеціалізується на розробленні та удосконаленні методів кількісного аналізу і методів обчислювального моделювання з метою збору специфічних знань на основі експериментальних даних, зокрема й тих, які відображають процес старіння. Це позиціонує системну біологію на контрасті з традиційними підходами, що вивчають окремі частини системи й у такий спосіб можуть упускати важливі поведінкові відповіді, які виникають у ході взаємодії цих окремих частин. Ураховуючи виняткову складність «старіючого» фенотипу та велику різноманітність клітинних систем, на які він впливає, абсолютно очевидно, що всебічне вивчення процесу старіння вимагає застосування підходів системної біології [19].

Комплексно дане питання детально представлено в монографії [9]. Деякі основні положення з монографії надамо в даній статті.

Регуляція біологічних процесів старіння та довголіття: молекулярні механізми. Майже 30 років тому в роботі [108] було представлено спробу національної класифікації теорій старіння на основі понад 300 варіантів. Незважаючи на їхню різноманітність, учені продовжують суперечку про існування єдиного (центрального) механізму старіння [8, 85]. Також існують як теоретичні, так і емпіричні докази наявності взаємозв'язків між механізмами старіння [1, 73, 74]. Феномен старіння складається із взаємопов'язаних процесів, що відбуваються на тканинному, клітинному, молекулярно-генетичному рівнях, а також на рівні цілісного організму. Вони включають регуляцію процесів підтримки гомеостазу, метаболічних реакцій, передавання внутрішніх і міжклітинних сигналів, накопичення нездатних до поділу клітин, пошкоджених органел і наномолекул, епігенетичні зміни та генетичну нестабільність [14, 39, 43, 75, 115]. Розвиток нових методів збору та оброблення інформації, технології «Великих даних» (Big Data), методів математичного моделювання, моделювання in silico дозволив із принципово нових позицій розглядати проблему старіння [16, 60, 64, 67, 68, 73, 114, 117 та інші].

Організмовий рівень прояву старіння включає в себе нездатність підтримувати сталість внутрішнього середовища організму, функціональні розлади та підвищення сприйнятливості до вікових захворювань. Такі перетворення часто пов'язані зі зміною кількості клітин і якісного складу тканин, порушенням механізмів міжклітинної сигналізації та активності систем відповіді на стрес і метаболічні зміни [85].

На тканинному рівні хронічне запалення виступає драйвером багатьох вік-залежних захворювань, насамперед, серцево-судинних і нейродегенеративних [6]. Розлади роботи клітин - ще один рівень, на якому відбувається старіння. 3 віком збільшується кількість нездатних до поділу (сенесцентних) клітин, посилюється утворення АФК у результаті зниження активності мітохондріального дихального ланцюга й антиокислювальних ферментів, запускається відповідь на денатурацію білків у мережі ендоплазматичного ретикулуму, а також виникає нездатність клітин відновлювати пошкоджені білки та підтримувати протеостаз за допомогою лізосом і протеасом [37, 45, 50].

На молекулярному рівні старіння проявляється нездатністю клітини повністю відновлювати пошкоджені макромолекули. При старінні накопичуються пошкоджені ділянки ДНК, акумулюються епігенетичні модифікації ДНК і гістонів, що призводить до перебудови хроматину [5]. При цьому відбувається гетерохроматизація найважливіших для життєдіяльності клітини ділянок хромосом (senescence-associated heterochromatin foci) та дегетерохроматинізація повторюваних послідовностей генома.

Відомо також, що стресостійкість пов'язана із довголіттям. Підвищення стресостійкості призупиняє зростання та репродукцію у тварин. Гормони осі GH (growth hormone, соматотропін)/ IGF-1 і контрольовані ними сигнальні шляхи (рецептор IGF-1 і його субстрати, кіназа PISK, AKT, mTOR, SGK) у сприятливих умовах навколишнього середовища забезпечують процеси зростання та розмноження організму, пригнічуючи при цьому енерговитратні процеси стресостійкості. Одним із шляхів індукції програми стресостійкості являється активація генів стрес-відповіді, багато з яких відіграють ключову роль у реалізації довголіття. До них можна віднести гени, що кодують фактори транскрипції FOXO (fork head box O protein), NRF2, HIF-1, кіназу JNK, сиртуїни та ряд інших білків [114]. В умовах стресового навантаження індукція FOXО викликає експресію генів клітинного 
захисту, таких як ген білка теплового шоку Hsp70, ген репарації ДНК GADD45, ген аутофагії $L C 3 b$, GABARAPL1 та Atg12 [103], лізосомальний ген $L A M P 1$, а також гени убіквітин-протеасомної деградації білків. Реалізація функції FOXO-регуляції білків відбувається за участю багатьох інших генів, асоційованих із довголіттям, наприклад АМРК, $P G C 1 \alpha, p 53$, SIRT1, SIRT6, NRF1, SREBP1, що задіяні у біогенезі мітохондрій, гліколізі, мітофагії, мітогормезі [112, 126].

Сиртуїни належать до родини нікотинамід-аденіндинуклеотид (NAD+)-залежних ферментів, що володіють деацетилазною та АДФ-рибозилтрансферазною активністю. Активність деацетилази SIRT1 індукується збільшенням внутрішньоклітинного співвідношення $\mathrm{NAD+/NADH}$ у відповідь на окиснювальний стрес у процесі старіння. Гомолог SIRT1 у безхребетних і дріжджів $\epsilon$ відповідальним за позитивний ефект впливу обмеження калорій на тривалість життя [114]. SIRT1 являється ключовим регулятором фізіологічних процесів, пов'язаних із вік-залежними станами, зокрема із цукровим діабетом 2-го типу, ожирінням, нейродегенеративними розладами та новоутвореннями. Також він відіграє важливу роль у процесі апоптозу. Інший представник родини сиртуїнів SIRT6 стимулює активність різних білків репарації ДНК у відповідь на стрес [101].

JNK - еволюційно консервативна протеїнкіназа, що активується в старості у відповідь на вплив стрес-факторів. 3 одного боку, JNK індукує активацію генів, що забезпечують захист клітини від негативних впливів шляхом підвищення активності факторів трансдукції FOXO і AP1, а з іншого боку - впливає на клітинний метаболізм, зростання та поділ через інсулінову IGF-1-сигналізацію [27]. Розлади регуляції JNK призводять до розвитку нейродегенеративних захворювань, метаболічних розладів і новоутворень.

IGF-1 і соматотропін (GH) являються стимуляторами зростання. Гормон-рецепторний комплекс GH/GHR, що володіє протеїнкіназною активністю, активує шлях JAK/STAT-сигналізації і стимулює експресію IGF-1. Циркулюючий у крові фактор зростання IGF-1 передає сигнал на поверхні клітин периферичних тканин. Рецептори трансдукують сигнал до білків IRS, що саме передають далі сигнал на кінази PIЗK, AKT/PKB i mTOR [108]. Проте, як уже зазначалося, відбувається деактивація енерговитратного процесу підтримання стресостійкості старіючих клітин.

TGF- $\beta$-сигналізація залучена до багатьох клітинних реакцій, таких як зростання, диференціювання, апоптоз, підтримка гомеостазу [22]. TGF- $\beta 1$ забезпечує індукцію генів-маркерів клітинного старіння та бере участь у формуванні сенесцентного фенотипу клітин в умовах стресу [24].

Фізіологічна відповідь на надходження поживних речовин - одне $з$ найбільш досліджуваних явищ у біології старіння. Найважливішу роль при цьому відіграє специфічний шлях Rheb/ mTOR/SGK/SG/4e-BP/eIF-4e, що складається iз двох гілок, регульованих комплексами mTOR i mTORC2. Перший із них відповідає за регуляцію трансляції - він активує p70, S64,S6, eIF-4e і репресує інгібітор трансляції 4е-8Р, біогенез рибосом, пригнічення аутофагії, здійснення гліколізу (HIF-1), васкуляризацію (VEGF), а також синтез жирних кислот (SREBP) [70]. mTORC2 бере участь у перебудові активного скелета, однак він інгібує транскрипційні фактори стрес-відповіді FOXO1 i FOXO3 за участю комплексу AKT-PKC-S6K та активує фактор транскрипції NF-kB, провокуючи запалення, канцерогенез і клітинне старіння [56].

До позитивних регуляторів тривалості життя відносяться мембранні корецептори рецепторів фактору зростання фібробластів (fibroblast growth factor) ( $\alpha$ - та $\beta$-Klotho), що індукують рівень гормону росту, IGF-1 і чутливість тканин до інсуліну [120]. При дефекті гену Klotho у тварин (миші) з'являються ознаки прискореного старіння, такі як остеопороз, атеросклероз, емфізема легенів, що призводять до сценарію ранньої загибелі. При нестачі Klotho встановлено розлади мінерального обміну, включаючи гіперкальціємію, гіперфосфатемію та гіпервітаміноз D [71].

Іншим прикладом білків, що сприяють довголіттю та регулюють метаболізм у старості, являється AMPK, запуск якої $є$ тригером підвищення співвідношення АМФ/АТФ унаслідок енергетичного голодування клітини, а також подальших розладів мітохондріального дихання та гіпоксії [32]. АМРК управляє низкою метаболічних шляхів, наприклад, поглинанням і утилізацією глюкози, окисненням ліпідів [59], та пов'язана із впливом активаторів АМРК (метформін, фенформін) на збільшення тривалості життя [104]. 
PPAR-рецептори, що активуються проліфераторами пероксисом, відносяться до групи ядерних регуляторів процесу транскрипції. PPAR активує ряд генів, що відповідають за метаболізм нітритів і підтримку рівня глюкози. Цей білок відповідальний за розвиток пов’язаної зі старінням резистентності до інсуліну та бере участь в інгібуванні хронічного запалення, що супроводжує процес старіння [95]. Підтримка цілісності генома при старінні пов’ язана 3 активністю ферменту полі(АДФ-рибози)полімерази-1 (РАРP1), що являється сенсором розривів ланцюгів ДНК [81]. Іншими найважливішими сенсорами двохланцюгових і одноланцюгових пошкоджень ДНК є ATM- і ATR-кінази, що забезпечують запуск перевірочних (кінцевих) точок клітинного циклу, ініціацію затримки клітинного циклу та репарацію ДНК. Вони фосфорилюють ключові білки сигнальних шляхів при відповіді на пошкодження ДНК при старінні, включаючи p53, Chk1, Chk2, Mdm2, NSB1, АMPK-сигналізацію [53]. Однією 3 найважливіших мішеней цих кіназ $є$ фактор транскрипції р53 [4]. Його активація необхідна для реалізації стрес-реакцій при клітинному старінні: від зупинки клітинного циклу та репарації ДНК до клітинної загибелі (апоптозу).

У підтримці цілісності геному велике значення відіграє активність теломерази. Вона являє собою зворотну транскриптазу та відповідає за синтез теломерної ДНК, що коротшає при кожному розподілі зрілих соматичних клітин. Незважаючи на те, що дані про кореляцію довжини теломер із тривалістю життя та швидкістю старіння суперечливі, встановлено, що при серцево-судинних захворюваннях людини виявляється значне вкорочення теломер у клітинах судинного ендотелію, а генотерапевтична активація теломерази у дорослих тварин забезпечує кардіопротекцію [124].

Протеостаз - сукупність механізмів, що забезпечують контроль якості клітинних білків. Розлади протеостазу виявляються біомаркером старіння [41] та негативно впливають на тривалість життя. Зниження експресії шаперонів, зокрема білків теплового шоку та їхнього основного регулятору фактору теплового шоку HSP1, негативно впливає на тривалість життя і стійкість до стрес-факторів на фоні збільшення утворення білкових агрегатів.

За процеси утилізації як надлишкових, так i пошкоджених білкових фрагментів клітин відповідальні убіквітин-протеасомна й аутофагічна системи, реалізуючи мету через протеасоми та лізосоми відповідно. Підвищення їхньої активності захищає клітини від протеотоксичного стресу та підтримує клітинний гомеостаз у процесі старіння. Ключовими білками мітохондрій, що впливають на процес старіння організму, являються TFAM і PGC12. Транскрипційний фактор мітохондрій A (transcription factor A, mitochondrial, TFAM) відіграє важливу роль у підтримці кількісного та якісного складу мітохондрій. Він забезпечує упаковку мітохондріальної ДНК (мтДНК) у мітохондріальні нуклеотиди, регулює реплікацію та репарацію мтДНК [102]. Відзначено, що з віком знижується експресія гену ТFАМ та здатність його білка зв’ язуватися з цією ДНК [46].

Сигнальні молекули гормонів, що виділяються жировою тканиною, називають адипокінами. До них відносяться адипонектин, лептин, резистин, TNF- $\alpha$, K-6/PAI-1. Ці молекули пов'язані з багатьма сигнальними шляхами клітини, що визначають старіння організму. Так, низький рівень адипонектину у плазмі крові людини вказує на розвиток хронічної ішемічної хвороби серця та може служити маркером передчасного старіння серцево-судинної системи [29]. Іншим прикладом асоційованих із старінням цитокінів є міостатин. Міостатини - це родина трансформуючих ростових факторів, які значно пригнічують зростання та диференціювання м'язової тканини під час старіння, що призводить до різних захворювань [110].

Селекція життєздатних клітин при старінні тісно пов’язана з механізмами програмованої клітинної загибелі - апоптозом. Поступове накопичення сенесцентних клітин у тканинах прискорює старіння організму. Їхня кількість у молодому організмі регулюється імунокліренсом, здатність до якого згасає з віком через старіння імунної системи. Одним із регуляторів апоптозу в старіючих клітинах $€$ сигнальний каскад Shc/Ras. У ссавців три ізоформи Shc (p52Shc, P46Shc i p66Shc) відповідають за пригнічення апоптозу та регуляцію тривалості життя [15], а такі ізоформи Shc, як p52Shc i p46Shc, передають і підсилюють сигнал від рецепторних тирозинкіназ до білків Ras. Ras - невеликі ГТФази, що беруть участь у трансдукції сигналів від рецепторних тирозинкіназ до сигнальних шляхів клітини, які відповідають за апоптоз і виживання 
старіючих клітин [66]. До таких шляхів відноситься сигнальний каскад мітоген-активованих каспаз (MAPK) і кіназ (ERK), що регулюють передавання в клітину позаклітинних сигналів. Встановлено, що ліпідактивація генів сімейства Ras $€$ причиною розвитку третини злоякісних новоутворень, які важко піддаються протипухлинній терапії [66].

Відомо, що гени циркулюючих ритмів, таких як цілодобові коливання різних фізіологічних показників і продуктів обміну, включені в значну кількість процесів, пов'язаних із старінням організму та, зокрема, з віковими патологічними станами. При нормальному старінні відзначаються розлади циклів сну та неспання, сон стає деконсолідованим, своєю чергою осциляції експресії генів циркадних ритмів втрачають робастність, а експресія змінює амплітуду або фазу зі втратою здатності до коливань [21, 127]. Так, білок добового ритму BMAL1, контрольований відповідним геном, впливає на швидкість старіння при взаємодії із комплексами сигнального каскаду MTOR [76]. Білок CLOOK активує прозапальний фактор NF-kB, зберігає тривалість життя, а надекспресія timeless cryptochrome знижує швидкість старіння. Всі ці зміни ініціюються суворо ієрархічною системою молекулярних осциляторів, що заснована на функціонуванні транскрипційно-трансляційних або трансляційно-трансляційних петель біологічного зворотного зв'язку, пов'язаних із старінням організму [113].

Особливості фізіологічної дисрегуляції при старінні та моделювання молекулярних механізмів вік-залежних процесів. Уже давно висловлюються думки, що старіння тісно пов'язане зі складною динамікою фізіологічних систем, які підтримують гомеостаз, і зокрема з дисфункцією регуляторних мереж молекул сигнальної трансдукції. Останнім часом підкреслюється важливість такої складної динаміки систем у процесі старіння [125]. Встановлено важливі докази того, що фізіологічна дисрегуляція, а саме поступове порушення здатності складних мереж підтримувати гомеостаз, являється емерджентною властивістю цих регуляторних мереж і відіграє важливу роль у процесі старіння.

Поряд із збільшенням розуміння ролі системної біології у вивчені старіння, активно розробляються такі напрями, як динаміка складних систем у процесі старіння, багатофакторні теорії старіння, загальний напрям розвитку системної біології та біоінформатики старіння, системна робастність $[52,55,79,96]$. Кожен із зазначених напрямів досліджень підкреслює складності процесу старіння, необхідність їх інтеграції та подальшого розроблення в довгостроковій перспективі.

Старіння також може бути багатофакторним процесом, заснованим на накопиченні альтераційних змін, що не поєднані складною системною динамікою [79]. Тому відмінності між багатофакторними теоріями та тенденціями складних систем можуть мати важливе значення для еволюціонування процесу старіння. Обгрунтування ролі складних систем у процесі вікових змін передбачає взаємодію між підсистемами та включає складні петлі біологічного зворотного зв'язку, коли проблеми в одній системі викликають нові проблеми в іншій [65]. Одні дослідники роблять акцент на комп’ютерному моделюванні динаміки процесу старіння, заснованому на детальному знанні структури системи, не надаючи особливої уваги її властивостям [79]. Тоді як інші працюють у галузі мережевої картографії [72], що дозволяє використовувати функціональну основу технологій високої пропускної здатності для створення цільової інтеграції великих масивів даних вікових змін [93]. Ще один підхід дозволяє інтегрувати структурну динаміку та функцію шляхом використання принципів проєктування складної мережевої динаміки систем у старості [52].

Однією з гіпотез мережевого підходу до аналізу складних вікових змін $€$ поняття точності (прецизійність, precision), що необхідна для успішного розуміння мережевої динаміки [30]. Зазначене дозволяє деталізувати лінійні та логістичні функції регуляторних мереж. Іншим напрямом досліджень складності (complexity) системи старіння $€$ робастність - властивість, що дозволяє системі підтримувати свої функції у відповідь на внутрішні та зовнішні «збурення» [83]. Зазначена гіпотеза передбачає, що під еволюцією робастності йдеться про еволюцію компромісів у високооптимізованих системах, а старіння може бути побічним ефектом численних аспектів еволюційної оптимізації розвитку систем на рівні організму.

Нарешті, втрата злагодженості (loss of complexity) системи старіння є ще однією гіпотезою, 
що відображає розуміння організму як складеної системи [96]. Втрата «складеності» в старості дозволяє реєструвати в організмі фрактальні патерни, а також хаотичні флуктуації, що сильно змінюються, або складні поєднання структурних змін. При цьому старіючий організм втрачає контроль над багатовимірними станами та динамічними процесами, що лежать в основі складеної організації систем. Проте втрата складності системи старіння не обов'язково пов'язана із мережею молекулярних взаємодій. Наприклад, із віком звичними предметами втрати злагодженості є варіабельність серцевого ритму та розлади розгалуження мікросудинної мережі [111], що призводить до порушення здатності адаптуватися до фізіологічного стресу. $\mathrm{У}$ майбутньому розкриття тонкого механізму втрати злагодженості, заснованого на тенденції хаосу та пов'язаній із нею геометричною концепцією фракталів, можуть забезпечити нові способи моніторингу старіння та перевірки ефективності конкретних утручань для зміни вік-залежного зниження адаптивного процесу [87, 121].

Багато досліджень молекулярних механізмів старіння зосереджено на конкретній теорії — накопичення соматичних мутацій, укорочення теломер, пошкодження білка або мітохондріальна дисфункція. Проте наприкінці $1990-x$ років було усвідомлено, що окремі механізми не можуть адекватно пояснити процес старіння [119] та необхідно розглядати взаємодію між цими різними механізмами (рис. 1).

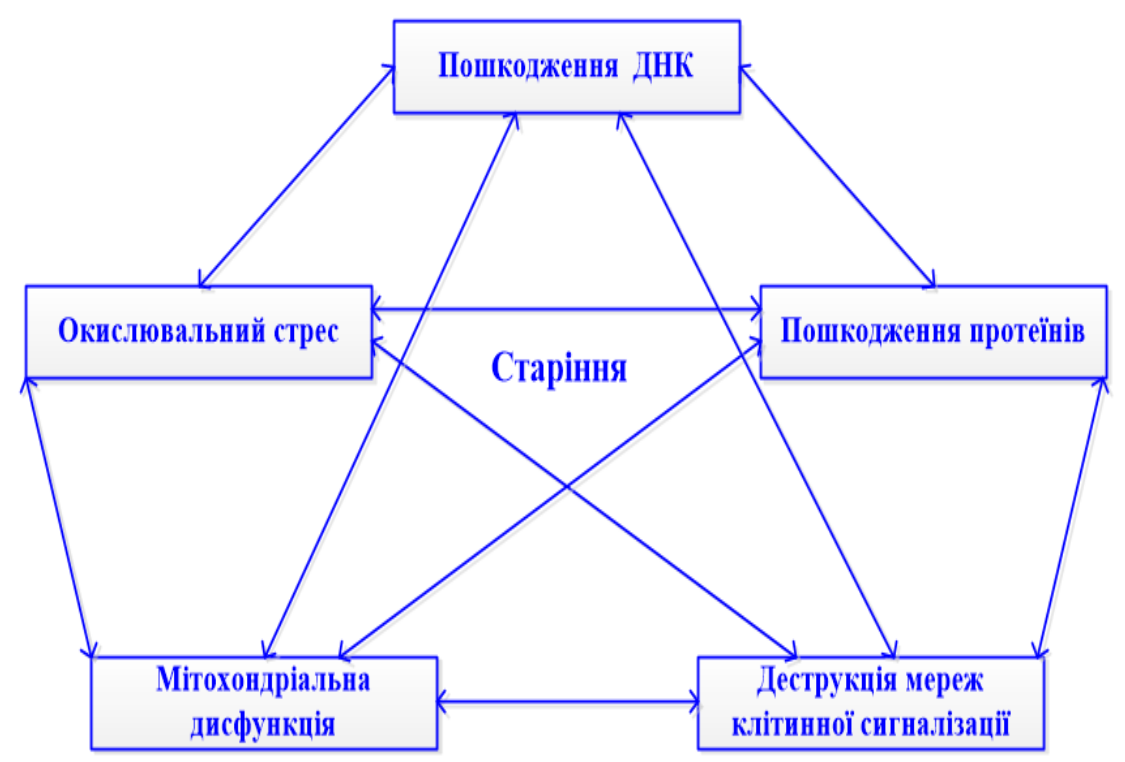

Рис. 1. Взаємодія молекулярних механізмів старіння. Схематично представлено приклади деяких основних механізмів і їх взаємодії

Наприклад, у результаті пошкодження мітохондрії виробляють більше активних форм кисню (АФК), що, зі свого боку, призводить до альтеративних змін практично всіх молекулярних компонентів. Зазначене зумовило те, що мережева теорія старіння та проблема вивчення складних взаємодій ініціювали одну з перших інтегрованих математичних моделей старіння [105]. Відтоді з'явилося багато нових технологій і можливостей отримання великих масивів даних, що вимагало прискореного розроблення нових інструментів аналізу та інтерпретації задля оптимізації процесу появи нових галузей системної біології [18, 100].
Моделі пошкодження та відновлення ДНК. Багато моделей запропоновано для дослідження ролі пошкодження ДНК на рівні клітинного старіння в культурі фібробластів [3, 82]. Ці моделі не включають особливості механізмів дволанцюгових розривів ДНК, відповідно до яких активізуються клітинні сигнальні шляхи (ATM/ATR p53, p21), що призводить до затримки клітинного циклу. Проте математичне моделювання виявило зв'язок таких подій із наявністю петель негативного зворотного зв'язку в системі р53, а також між р21 і продукцією АФК [48, 109]. Експериментально підтверджено, що АФК функціонує в складі 
петлі позитивного зворотного зв'язку для активації та підтримки клітин у фазі реплікативного старіння [7, 116].

Моделі укорочених теломер. Відомо, що повторювані послідовності ДНК, що захищають кінці лінійних хромосом (теломери) в соматичних клітинах людини, скорочуються з кожним наступним діленням клітини внаслідок відсутності кінцевої реплікації. Перші математичні моделі укорочених теломер як реплікативного клітинного старіння (межа Хейфліка) були експериментально підтверджені та показали, що окиснювальний стрес $\epsilon$ важливим фактором, який призводить до вкорочення на порядок теломерів лінійних хромосом [92, 122]. Автори висловили припущення, що результат реплікативного клітинного старіння залежить не лише від вихідної (критичної) довжини теломер, а й обумовлений індукцією утворення так званих розщеплюючих Т-петель біологічного зворотного зв'язку.

Моделі протеостазу (втрата гомеостазу протеїнів) i шаперонінгу. Білковий гомеостаз підтримується так званими системами контролю якості, а саме такими як синтез білка, фолдинг, рефолдинг, анфолдинг [86]. Протеїни дуже чутливі до окиснювального пошкодження і це призводить до їхніх конформаційних або ковалентних (незворотних) змін. Конформаційні зміни можуть бути оборотними завдяки молекулярним шаперонам, що зв'язуються гідрофобними поверхнями та допомагають у рефолдингу. Виявилося, що шаперони можуть також брати участь у секвестуванні (sequestering) пошкоджених білків, а клітинне старіння розцінюється як стан, обумовлений шапероновим перевантаженням (overload) і протеотоксичністю (proteotoxicity) [69]. Стохастичне моделювання дії шаперонів (Hsp70/Hsp90) та їхньої ролі при старінні показало, що шаперонінг здатний підтримувати білковий гомеостаз в умовах слабкого або перехідного стресу [40]. Проте хронічний стрес зрештою призводить до того, що баланс між шаперонами та неправильно складеними білками зникає і дані білки утворюють агрегати. Розширення моделювання в напряму апоптозу показало, що клітини із високим рівнем умісту неправильно складених білків можуть розвиватися відповідно до сценарію запрограмованої клітинної загибелі [129].
Дві системи клітини (аутофагична та протеасомна) беруть участь в усуненні пошкоджених білків. Використання in silico моделі функціонування убіквітин-протеасомної системи, що включає нормальний і залежний від віку гомеостаз, дозволило спрогнозувати збільшення вмісту агрегованого протеїну та зниження гомеостазу протеїнів із віком. Аутофагічна система включає в себе макроаутофагію та шаперон-опосередковану аутофагію, що схильні до функціонального зниження в старості [34]. Активація шаперон-опосередкованої аутофагії регулюється окиснювальним стресом із метою селективної деградації і видалення окиснених цитозольних білків лізосомами [78].

Моделі мітохондріального старіння. Математичне моделювання динаміки мітохондріального старіння дозволило проаналізувати гомеостатичні механізми, що регулюють рівні АФК і функціонування мітохондрій [89]. Автори розробили комплексну обчислювальну модель, що охоплює продукцію мітохондріальних АФК у різних станах енергетики мітохондрій, які визначаються ритмом серця. Моделювання допомогло встановити взаємозв'язок між дисфункціональним виробленням іонів кальцію та підвищеною продукцією АФК мітохондріями внаслідок підвищення рівня цитозольного натрію, виявленого в кардіоміоцитах, що старіють [57]. Встановлено, що петля біологічного зворотного зв’ язку між активацією р21 і продукцією АФК, яка тригеризує реакції пошкодження ДНК, сприяє формуванню стану «глибокого» клітинного старіння. Такий стан був пов'язаний із активацією гену CDKN1A (р21), наслідком чого стало виникнення мітохондріальної дисфункції і продукції АФК через GADD45-MARK14 (p38 MARK)-GRB $\beta$-TGFbR2-TGF $\beta$-сигналізацію. Автори вважають, що ця петля необхідна та достатня для забезпечення стійкості фенотипу старіння [20, 116].

Моделі дисрегуляції клітинної сигналізації. Ser/THR-кіназа i mTOR існують у двох структурно та функціонально різних комплексах (mTORC1 i mTORC2), що є високоінтегрованими сигнальними вузлами. 3 віком численні білки в мережі mTOR стають дисрегульованими $[47,53]$. Інтеграція динамічної мережевої моделі mTOR із математичною моделлю клітинного старіння дозволила виявити потенційно нові підходи для гальмування старіння 
клітини [47]. Зв'язки між mTOR та інсуліновою сигналізацією були покладені в основу при створенні математичних моделей тестування механізмів інсулінорезистентності адипоцитів людини [31] із визначення петлі біологічного зворотного зв'язку між mTOR та інсуліновою сигналізацією при цукровому діабеті 1-го типу.

Розшифрування особливостей TGF. Бетасигналізація прискорила розроблення моделей клітинного старіння. Так, у роботі [105] представлена спочатку створена модель TGF-сигналізації, яка показала, що рецептори TGF є не тільки перетворювачами сигналів трансдукції, але й виявляються ключовими модуляторами реакції TGF $\beta$ сигналізації. Модель [14], яка була деталізована змінами рецепторів TGF $\beta$ із плином часу, показала, що вони сприяють розвитку артриту в похилих осіб. Автори вважають, що розуміння динаміки рецепторів, а також того, як вони змінюються з віком, має велике значення для багатьох захворювань, і обчислювальне моделювання може відігравати першорядну роль в аналізі цього процесу.

Сигналізація NF-кB опосередковує експресію генів, які впливають на ряд біологічних процесів, включаючи імунітет, запалення, диференціювання клітин, апоптоз, клітинне старіння, що активуються цілою низкою стимулів, включаючи інфекції, АФК і асоційоване $з$ віком пошкодження ДНК [122]. Підвищення активності NF-кB пов'язане з появою хвороб старіння (вікових захворювань), тоді як інгібування NF-кB обумовлює відстрочену появу вікових захворювань.

Моделі епігенезу. Зростає число підтверджень того, що стан метилювання ДНК (епігенетичний процес) і клітинне старіння нерозривно пов'язані. Так, статистичний аналіз даних метилювання ДНК і байєсівське моделювання дозволили оцінити час початку хвороби у пацієнтів із стравоходом Барретта [118]. При цьому «молекулярний годинник» визначає вік гетерогенних тканин при синдромі Барретта, що являється метапластичним попередником аденокарциноми людини і як своєрідний біомаркер допомагає контролювати ризик розвитку злоякісного процесу завдяки відстеженню вікового метиломного дрейфу (methylomic drift). Автори постулюють, що диференціація метиломного дрейфу в клітинах із метаплазією дозволяє здійснювати кількісне оцінювання періоду, протягом якого у пацієнта розвивається синдром Барретта з переходом у злоякісних процес.

Створення динамічної моделі метилювання/ деметилювання ДНК, заснованої на активності білків DNMT із додаванням білків сімейства Tet, що ферментативно перетворюють метилцитозин у гідроксиметилцитозин, дозволило оптимально точно передбачити експериментально підтверджені зміни кількості повнофункціональних білків DNMT i Tet у клітині та забезпечити точне прогнозування основних епігенетичних процесів, пов'язаних із модифікацією ДНК при гематологічних злоякісних новоутвореннях у старості [106]. Використання стохастичної моделі для вивчення вікових змін метилювання ДНК у гемопоетичних клітинах дозволило виявити активізацію самонаведення молодих гемопоетичних стовбурових клітин у нішах кісткового мозку, що уповільнює епігенетичне старіння [130].

Математичне моделювання зіграло унікальну роль у тому, щоб допомогти оцінити динаміку впливу мікроРНК (регуляторів епігенезу) в управлінні процесами клітинного старіння. Відомо, що мікроРНК - це невеликі некодуючі РНК, які регулюють білок-кодуючі гени через посттранскрипційну репресію. Зокрема моделювання допомогло виявити петлі біологічного зворотного зв'язку в мережах, опосередкованих мікроРНК, і виявити взаємодії між ними при регуляції генів [44]. В аспекті клітинного старіння розроблено математичну модель регуляції за допомогою мікроРНК систем внутрішньоклітинної сигналізації при злоякісних новоутвореннях [88], модель на основі сигнального шляху p53/Sirt1 для вивчення регулюючого впливу miR-34 $\alpha$ на SIRT1опосередковану р53-сигналізацію. Проведений аналіз дозволив структурувати можливі варіанти механізму інгібування, що чиниться мікроРНК-34 $\alpha$ на р53 через вплив на Sirt1.

На закінчення важливо представити, як теоретичні положення еволюційної медицини можливо реалізувати в практичній площині. Відповідь дає одна з електронних платформ здоров’я «Moniheal», розроблена останніми роками.

Інформаційні аспекти відображення здоров'я людини. Розроблена платформа «MoniHeal» - інноваційний багатофункціональний онлайнсервіс постійного моніторингу та профілактики 
стану здоров'я користувачів платформи за допомогою системи аналізу персональних показників, а також своєчасної корекції їх відхилень з метою ефективного попередження тяжких хронічних захворювань. Ї̈̈ місія полягає в залученні громадян до здорового способу життя через систему постійного контролю (моніторингу) стану свого здоров’я та оперативного реагування медичної системи при зміненні показників стану здоров'я, що потребують корекції з метою профілактики тяжких хронічних захворювань у майбутньому. Ще одним завданням $€$ виховання здорового покоління, яке дбатиме про своє здоров'я з самого початку свого життя та до похилого віку на засадах упровадження культури постійного контролю за станом свого організму задля збереження життя.

Платформа надає можливість користувачу залучити лікарів країни та медичної спільноти будьякого регіону світу для кваліфікованих консультацій і лікування. Такий сервіс надає можливість людині вже від народження мати повну інформацію про стан свого здоров'я та зберегти його високі показники впродовж довгих років життя до похилого віку.

Простий і зручний у користуванні сервіс має стати невід'ємною складовою сучасної системи охорони здоров'я, він має забезпечити постійний моніторинг стану власного здоров'я користувача та здоров'я його близьких, а також забезпечити своєчасну кваліфіковану медичну допомогу спеціалістів для корекції відхилень показників стану здоров'я, виявлених у процесі моніторингу.

Мета програми, що закладена в платформі «MoniHeal», включає всі стратегії забезпечення індивідуального здоров’я, а саме:

1. Постійний моніторинг стану особистого здоров'я користувача.

2. Оперативне коригування будь-яких відхилень, виявлених у процесі постійного моніторингу стану його здоров'я.

3. Суттєве зменшення ймовірності виникнення онкологічних, серцево-судинних та інших хронічних небезпечних для людини захворювань.

4. Психологічна впевненість користувача програми у власних кондиціях здоров'я.

Платформа «MoniHeal» дозволяє відстежувати динаміку індивідуальних показників здоров’я у зручній зрозумілій для пацієнта формі візуалізованих графіків, а хронологія змін показників надає можливість сімейним лікарям і персональним медичним менеджерам дистанційно ефективно контролювати та управляти станом здоров'я пацієнта.

Платформа «MoniHeal» може пропонувати обгрунтований план консультацій і досліджень, орієнтуючись на вік, стать, перенесені захворювання, шкідливі звички, а сімейний лікар має можливість коригувати цей план, керуючись об’єктивним оцінюванням поточного стану здоров'я свого пацієнта та аналізом даних еволюційної медицини.

Після виконання скринінгу користувач може активувати персональну програму моніторингу, що супроводжує користувача постійно, підказуючи, коли й які дослідження та аналізи є необхідними для проходження. По суті, моніторинг стає інструментом ранньої діагностики та попередження захворювань і тяжких наслідків для організму людини. Це означає, що користувач за допомогою сімейного лікаря або персонального медичного менеджера гарантовано виявить і попередить захворювання, перешкодить прогресу захворіння, нанесенню шкоди здоров’ю або розвитку загрози для життя. Як і в стратегії скринінгу, лікар також має можливість корегувати цей план: додавати чи відміняти окремі дослідження й обстеження.

Захист персональних даних, що оброблюються програмними засобами платформи, відбувається як шляхом здійснення організаційних заходів, так і з використанням технічних засобів із метою недопущення витоку таких даних, незаконного чи несанкціонованого доступу до них будь-яких третіх осіб, а також шляхом їхнього шифрування та/або знеособлення (вилучення відомостей, що дають змогу прямо чи опосередковано ідентифікувати особу). Платформа налаштована таким чином, щоб унеможливити зловживання чи неякісне користування нею. Для цього є певна система противаги, що закладена в систему та реалізована за допомогою арбітражу. Якщо клієнт із будь-яких причин не отримав консультацію чи вважає дії лікаря непрофесійними, він має можливість подати на платформі скаргу на лікаря, з метою повернення зарезервованих коштів або зробити відповідний відгук у системі рейтингів.

Важливим елементом платформи $є$ механізми фіксації нових даних, отриманих під час візитів 
до лікаря. Все, що потрібно клієнтові, додається у вигляді документу до медичного архіву з урахуванням часової мітки, опису та категорії консультації. У разі проведення віддаленої консультації з телефону аудіо- та відеозапис консультації відбувається у фоновому режимі. Потреби проводити ручне додавання результатів немає.

Пацієнт на платформі може бачити всі показники свого здоров’я, такі як артеріальний тиск, маса тіла, показники інструментальних обстежень та інші, вграфічному вигляді. Система автоматично формує графік змін показників стану здоров’я за запитом користувача чи лікаря, ретельно зіставляючи реальні дані показників стану здоров’я пацієнта протягом усього часу користування платформою, порівнюючи з референтними значеннями та візуалізуючи їх. Донесення до пацієнтів інформації передусім візуально обумовлено прагненням забезпечити максимальну доступність проблемних параметрів їхніх показників стану здоров’я. Користувачі мають змогу провести синхронізацію програми скринінгу та моніторингу свого здоров’я чи членів своєї родини у зручному форматі, зокрема за допомогою електронної пошти. Це дозволяє отримувати оперативні повідомлення на всі доступні гаджети та завжди пам’ятати про свої найближчі дії за програмою скринінгу чи моніторингу.

Розсилаються автоматично користувачам (на комп’ютери, мобільні пристрої) повідомлення, що повертають користувачів у потрібні місця на платформі, які вони вже відвідували. Отже, технічні можливості платформи дозволяють розробити більш продуктивну та «чуйну» до користувачів систему.

При створенні глобальної мережі на платформі «MoniHeal» можливо отримати необхідну інформаційну медичну послугу, наприклад пошук усіх спеціалістів, скористатись необхідними фільтрами для точного підбору їх спеціалізації та зручних умов отримання консультації. Іншими словами, за допомогою детального пошуку є можливість знаходити спеціаліста за багатьма критеріями: його місцезнаходженням, вартістю послуги, рейтингом, відгуками. Відеозапис консультації не дозволить випустити важливе з уваги.

Лікар може ініціювати проведення консиліуму, залучивши послуги своїх колег в інтересах пацієнта після погодження $з$ ним. Платформа надає можливість робити це в режимі онлайн (якщо зібрати спеціалістів в умовах клініки важко). Онлайн-консиліум відбувається у вікні чату, де присутній кожен лікар, після вивчення архівних даних пацієнта та історії недуги. Після завершення консиліуму сімейний лікар фіксує заключення та відправляє його в медичний архів пацієнта. Зрозуміло, що після завершення консиліуму в медичному архіві будуть доступними всі матеріали, заключення та відеозаписи консультацій, які були проведені.

Вкрай важливими є формати використання віддаленої комунікації між учасниками платформи. На платформі «MoniHeal» використовуються системи автоматичного перекладу комунікацій на мови спілкування учасниками платформи, забезпечується текстовий/відеозапис усіх розмов із доповненням до медичного архіву.

Платформа «MoniHeal» забезпечує контроль якості медичних послуг шляхом створення підсистеми відгуків усіх учасників лікувально-діагностичного процесу (пацієнтів, сімейних лікарів, вузьких спеціалістів).

Висновки. 1. Еволюційна медицина зміщує акцент із дихотомічного розгляду здоров'я та захворювань на більш контекстуальний розгляд. Підкреслюються необхідність трансдисциплінарного синтезу дисциплін про здоров'я людини.

2. Створена віртуальна сервісна програма відслідковування стану здоров'я людини, що дає можливість протягом усього її життя реєструвати всі зміни стану здоров’я та сприяти своєчасній корекції патологічних змін. Платформа є реальним втіленням загальновідомої істини - упередити хворобу простіше, ніж її вилікувати.

3. Питання, чи $є$ еволюційна медицина фундаментальною наукою - важливим світоглядом узагальнення проблем здоров'я та захворювань — залишається. Застосування еволюційної перспективи до клінічної практики хоча не впливає на повсякденні терапевтичні рішення, але може призвести до нових клінічних стратегій. Тим не менш, клінічна медицина та громадська охорона здоров’я насамперед зосереджені на етіології, профілактиці та лікуванні захворювань, а вже потім на зміцненні здоров’я. Ця невідповідність і є причиною того, що лікарі не завжди правильно розставляють акценти в різних формах своєї діяльності. 


\section{Література.}

1. Анисимов В. Н. Молекулярные и физиологические механизмы старения. - СПб.: Наука, 2003. - 468 с.

2. Артемов А. В., Бурячковский Е. С. Старение: различия между смертью клетки и смертью организма с позиции математической модели // Украинский журнал медицины, биологии и спорта. - 2016. T. 3 (1). - С. 215-220.

3. Войтенко В. П. Математическое моделирование в геронтологии // Геронтология и гериатрия: ежегодник. Иммунитет и старение. Сб. статей. - К., 1987. С. $118-130$.

4. Воропаева Е. Ф., Шокин Ю. Н., Непомнящих Л. М. Математическое моделирование функционирования системы белков р53-MDM2 // Бюлл. экспер. биол. и мед. - 2014. - № 2. - С. 261-264.

5. Галицкий В. А. Эпигенетическая природа старения // Цитология. - 2009. - Т. 51 (2). - С. 388-397.

6. Герасименко Н. Д., Дегтярь Н. И., Расин М. С. Системное воспаление и старение: роль ядерных транскрипционных факторов терапевтической возможности // Проблемы старения и долголетия. - 2016. - Т. 25 (4). - С. 554-561.

7. Донцов В. И. Методология сущностного моделирования старения и ряд моделей, построенных с ее помощью // Труды ИСА РАН. - 2006. - Т. 19. C. 94-116.

8. Крутько В. М., Донцов В. И. Системные механизмы и модели старения. - M., URSS Pгеss, 2008. - 156 с.

9. Мінцер О. П., Заліський В. М. Системна біомедицина. Т.1. - К.: Інтерсервіс, 2019. - 550 с.

10. Михеев А. Н. Проблемы теории биологической эволюции (Пролегомены эволюционистики). К.: Фитоцентр, 2014. - 199 с.

11. Новосельцев В. М., Новосельцева Ж. А., Яшина И. Математическое моделирование в геронтологии - стратегические перспективы // Успехи геронтологии. - 2003. - № 12. - С. 149-165.

12. Халявкин А. В., Крутько В. М. Подход к моделированию старения с позиции биофизики сложных систем // Труды ИСА РАН. - 2006. - Т. 19. C. 117-155.

13. AAMC-HHMI. Scientific Foundation for Future Physicians Committee. Scientific Foundations for Future Physicians. Washington, DC: American Association of Medical Colleges and Howard Hughes Medical Institute, 2009.

14. A computer simulation approach to assessing therapeutic intervention points for the prevention of cytokine-induced cartilage breakdown / Proctor C. J. et al. // Arthritis Rheumatol. - 2014. - Vol. 66 (4). P. 979-989.

15. Aging and calorie restriction oppositely affect mitochondrial biogenesis through TFAM binding at both origins of mitochondrial DNA replication in rat liver / Picca A. et al. // PLoS ONE. - 2013. Vol. 8 (9). - P. e74644.
16. A hybrid model of mammalian cell cycle regulation / Sighania R. et al. // PLoS Comput. Biol. - 2011. Vol. 7 (2). - P. e1001077.

17. Akey J. M. Constructing genomic maps of positive selection in humans: where do we go from here? // Genome Res. - 2009. - Vol. 19 (5). - P. 711-722.

18. A molecular clock inters heterogeneous tissue age accusing patients with Barrett’s esophagus / Curtius K. et al. // PloS. One. - 2016. - Vol. 12 (5). - P. e1004919.

19. A new vision for old age. Rethinking health policy for Europe's ageing society. A report from the Economist Intelligence Unit // The Economist Intelligence Unit Limited. - 2012. - 4. - Режим доступу: https:// www.learneurope.eu/files/5613/7525/7796/Repensando_la_poltica_de_salud_sociedad_europea_ envejecida.pdf.

20. An integrated mitochondrial ROS production and scavenging model: implications for heart failure / Gauthier L. D. et al. // Biophys. J. - 2013. - Vol. 105 (12). - P. 2832-2842.

21. Annotation and merging of SBML models with semantic SBML / Krause F. et al. // Bioinformatics. 2010. - Vol. 26 (3). - P. 421-428.

22. Aschner Y., Downey G. P. Transforming growth factorbeta: master regulator of the respiratory system in health and disease // Am. J. Respir. Cell Mol. Biol. 2016. - Vol. 54 (5). - P. 55-647.

23. Association between physical activity and quality of life in the elderly: a systematic review, 2000-2012 / Gislaine C. et al. // Rev. Bras. Psiquiatr. - 2014. - Vol. 36 (1). P. 76-88.

24. A system analysis of age-related changes in some cardiac aging traits / Govihdarajn D. R. et al. // Biogerontology. - 2014. - Vol. 15 (2). - P. 139-152.

25. Barja $\mathrm{G}$. The mitochondrial free radical theory of aging // Prog. Mol. Biol. Transl. Sci. - 2014. - Vol. 127. P. 1-27.

26. Barreiro L. B., Quintana-Murci L. From evolutionary genetics to human immunology: how selection shapes host defense genes // Nat. Rev. Genet. - 2010. Vol. 11. - P. 17-30.

27. Biochemical genetic pathways that modulate aging in multiple species / Bitto A. et al. // Cold Harbor Persp. Med. - 2015. - Vol. 5 (11). - P. a025114.

28. BioModels: ten-year anniversary / Chelliah V. et al. // Nucleic Acids Res. - 2015. - Vol. 43. - P. D542- D548.

29. Bridging the gaps in system biology / Cvijowic M. et al. // Mol. Genet. Genomics. - 2014. - Vol. 289 (5). P. 727-734.

30. Bridging the scale: semantic integration of quantitable SBML in graphical multi-cellular models and simulation with EPISM and COPASI / Sutterlin T. et al. // Bioinformatics. - 2013. - Vol. 29 (2). - P. 223-229.

31. Budanov A. V., Karin M. p53 target genes sestrin 1 and sestrin 2 connect genotoxic stress and mTOR signaling // Cell. - 2008. - Vol. 134 (3). - P. 451-460. 
32. Carrol B., Hewitt G., Korolchuk V. I. Autophagy and ageing: implications for age-related neurodegenerative diseases // Essays Biochem. - 2013. - Vol. 55. P. 119-131.

33. Caseinkinase $1 \alpha$-dependent feedback loop controls autophagy in RAS-driven cancer / Cheong J. K. et al. // J. Clin. Invest. - 2015. - Vol. 125 (4). - P. 1401-1418.

34. Chen D., Guarente L. SIR 2: a potential target for calorie restriction mimetics // Trends. Mol. Med. - 2007. Vol. 13 (2). - P. 64-71.

35. Convergent adaptation of human lactase persistence in Africa and Europe / Tishkoff S. A. et al. // Nature Genetics. - 2007. - Vol. 39 (1). - P. 31-40.

36. Core principles of evolutionary medicine: A Delphi study / Grunspan D. Z. et al. // Evol. Med. Public Health. - 2017. - Vol. 2018 (1). - P. 13-23.

37. Corper A., Stucki M. Chromatin maintenance and dynamics in senescence: a spotlight on SAHF formation and the epigenome of senescent cells // Chromosoma. - 2014. - Vol. 123 (5). - P. 423-436.

38. Cybulski M., Krajewska-Kulak E., Jamiolkowski J. Preferred health behaviors and quality of life of the elderly people in Poland // Clin. Interv. Aging. 2015. - Vol. 10. - P. 1555-1564.

39. Crespi B. J. The emergence of human-evolutionary medical genomics // Evolutionary Applications. 2010. - Vol. 4 (2). - P. 292-314.

40. Decreased proteasomal activity causes age-related phenotypes and promotes the development of metabolic abnormalities / Tomaru U. et al. // Am. J. Pathol. - 2012. - Vol. 180 (3). - P. 963-972.

41. Detection of a novel, integrative aging process suggest complex physiological integration / Cohen A. A. et al. // PLoS One. - 2015. - Vol. 10 (3). - P. e0116489.

42. Dinsdale N., Nepomnaschy P., Crespi B. The evolutionary biology of endometriosis // Evol., Med. Pub. Health. - 2021. - Vol. 9 (1). - P. 174-191.

43. DNA damage innormally and prematurely aged mice / Maslov A. Y. et al. // Aging Cell. - 2013. - Vol. 12 (3). - P. 467-477.

44. DNA double-strand break repair: a theoretical framework and its applications / Murray .P. J. et al. // J. R. Soc. Interfase. - 2016. - Vol. 13 (114). P. 20150679.

45. Dynamic modeling of pathways to cellular senescence reveals strategies for targeted intervention / Dalle Pezze P. et al. // PloS. Comput. Biol. - 2014. - Vol. 10 (8). P. e1003728.

46. Dynamic modeling of the interaction between autophagy and apoptosis in mammalian cells / Tavassoly I. et al. // CPT Pharmacometrics Drug Pharmacol. - 2015. Vol. 4 (4). - P. 263-272.

47. Efeyan A., Zoncu R., Sabatini D. H. Amino acids and mTORC1: from lysosomes to disease // Trends Mol. Cell Biol. - 2016. - Vol. 18 (9). - P. 33-524.
48. Effects of age, sex, and genotype on gene-sensitivity metabolomic profiles in the bruit fry, Drosophila melanogaster / Hoftman J. M. et al. // Aging Cell. 2014. - Vol. 13 (4). - P. 596-604.

49. Eurostat Statistics Explained. - Режим доступу: http://ec.europa.eu/ eurostat/statistics-xplained/index. php/Fertility_statistics\#Main_statistical_findings.

50. Feedback between $\mathrm{p} 21$ and reactive oxygen production is necessary for cell senescence / Passos J. F. et al. // Mol. Syst. Biol. - 2010. - Vol. 6. - P. 347.

51. Fogel R W. The escape from hunger and premature death, 1700-2100: Europe, America and the Third World. - Cambridge: Cambridge University Press, 2004.

52. Folate and DNA methylation: are view of molecular mechanism and the evidence for folates role / Crider K. S. et al. // Adv. Nutr. - 2012. - Vol. 3 (1). - P. 21-38.

53. Garcia-Martinez J. M., Alessi D. R. mTOR complex 2 (mTORC2) controls hydrophobic motif phosphorylation and activation of serum and glucocorticoid-induced protein kinase 1 (SGK 1) // Biochem. J. - 2008. Vol. 416 (3). - P. 375-385.

54. Halverson M. S., Bolnick D. A. An ancient DNA test of a founder effect in Native American ABO blood group frequencies // Am. J. Phys. Anthropol. - 2008. Vol. 137 (3). - P. 342-347.

55. Haploinsufficiency of myostatin protects against aging-related declines in muscle function and enhances / Mendias C. L. et al. // Aging Cell. - 2015. Vol. 14 (4). - P. 704-706.

56. Herskovitz A. Z., Guarente L. SIRT1 in neurodevelopment and brain senescence // Neuron. 2014. - Vol. 81 (3). - P. 471-483.

57. Hill S. M., Hauzen S., Nystrom T. Restricted access: spatial sequestration of damage proteins during stress and aging // EMBO Rep. - 2017. - Vol. 18 (3). P. 377-391.

58. How evolutionary principles improve the understanding of human health and disease / Gluckman P. D. et al. // Evol. Appl. - 2011. - Vol. 4 (2). - P. 249-263.

59. Insulin signaling in type 2 diabetes: experimental and modeling analyses reveal mechanisms of insulin resistance in human adipocytes / Brannmark C., Nyman E., Fagerholm S. et al. // J. Biol. Chem. - 2013. Vol. 288 (14). - P. 9867-9880.

60. Integrated stochastic model of DNA damage repair by Non-homologous end joining and p53/p21-mediated early senescence signaling / Dolan D. et al. // PloS Compat. Biol. - 2015. - Vol. 11 (5). - P. e1004246.

61. Jablonka E., Raz G. Transgenerational epigenetic inheritance: prevalence, mechanisms, and implications for the study of heredity and evolution // Quarterly Review of Biology. - 2009. - Vol. 84 (2). - P. 131-176.

62. Kaplan H. S., Robson A. J. We age because we grow // Proceedings of the Royal Society B-Biological Sciences. - 2009. - Vol. 276 (1663). - P. 1837-1844. 
63. Keywords and concepts in evolutionary developmental biology / Eds: Hall B. K. \& Olson W. M. - New Delhi, India: Discovery Publishing House, 2007.

64. Kirkwood T. B. Evolution of ageing // Nature. 1977. - Vol. 270. - P. 301-304.

65. Kirkwood T. B. Systems biology of ageing and longevity // Philos. Trans. R. So. Lond. B. Biol. Sci. 2011. - Vol. 366 (1561). - P. 64-70.

66. Kirkwood T. B. Understanding the odd science of aging // Cell. - 2005. - Vol. 120 (4). - P. 437-447.

67. Kirkwood T. B. L., Proctor C. J. Somatic mutations and ageing in silico // Mech. Ageing Dev. - 2003. Vol. 124 (1). - P. 85-92.

68. Kirkwood T. B. L. Why and how are we living longer? // Exp. Physiol. - 2017. - Vol. 102 (9). - P. 1067-1074.

69. Kitano H. Towards a theory of biological robustness // Mol. Syst. Biol. - 2007. - Vol. 3. - P. 137.

70. Klotho co receptors inhibit signaling by paracrine fibroblast growth factor 8 subfamily ligands / Goetz R. et al. // Mol. Cell. Biol. - 2012. - Vol. 32 (10). P. 1944-1954.

71. Kowald A., Kirkwood T. B. Accumulation of defective mitochondria through delayed degradation of damaged organelles and its possible role in the ageing of postmitotic and dividing cells // J. Theor. Biol. - 2000. Vol. 202 (2). - P. 145-160.

72. Kowald A., Kirkwood T. B. A network theory of aging: the interactions of defective mitochondria, aberrant proteins, free radicals and scavengers in the aging process // Mutat. Res. - 1996. - Vol. 316 (5-6). P. 209-236.

73. Kowald A., Klipp E. Mathematical models of mitochondrial aging and dynamics // Prog. Mol. Biol. Transl. Sci. - 2014. - Vol. 127. - P. 63-92.

74. KrieteA., Bost W. J., Booker G. Rule-based cell systems model of aging using feedback loop motifs mediated by stress responses // PLoS Comput. Biol. - 2010. Vol. 6 (6). - P. e1000820.

75. Kriete A. Robustness and aging - a systems level perspective // Biosystems. - 2013. - Vol. 112 (1). P. 37-48.

76. Labbadia J., Morimoto R. I. The biology of proteostasis in aging and disease. Annu. Rev. Biochem. 2015. Vol. 84, P. 435-464.

77. Laland K. N., Odling-Smee J., Myles S. How culture shaped the human genome: bringing genetics and the human sciences together // Nat. Rev. Genet. - 2010. Vol. 11. - P. 137-148.

78. Lai X., Wolkenhauer O., Vera J. Modeling miRNA regulation in cancer signaling system: miR-34 $\alpha$ regulation of the p53/Sirt1 signaling module // Methods Mol. Biol. - 2012. - Vol. 880. - P. 87-108.

79. Lai X., Wolkenhauer O., Vera J. Understanding microRNA-mediated gene regulatory networks through mathematical modeling // Nucleic Acids Res. - 2016. - Vol. 44 (13). - P. 6019-6035.
80. Lee R. D. Rethinking the evolutionary theory of aging: Transfers, not births, shape senescence in social species // PNAS. - 2003. - Vol. 100 (16). - P. 96379642.

81. libRoadRunner: a high performance SBML simulation and analysis library / Somogyi E. T. et al. // Bioinformatics. - 2015. - Vol. 31 (20). - P. 3315-3321.

82. Lipsitz L. A., Goldberger A. L. Loss of 'complexity' and aging. Potential applications of fractals and chaos theory to senescence // JAMA. - 1992. - Vol. 267 (13). - P. 1806-1809.

83. Marin-Garcia J. Mitochondrial DNA repair: a novel therapeutic target for heart failure // Heart Fail. Rev. 2016. - Vol. 21 (5). - P. 87-475.

84. Mc Govern A. P., Powell B. E., Chevassut T. J. A dynamic multi-compartmental model of DNA methylation with demonstrable predictive value in hematological malignance // J. Theor. Biol. - 2012. Vol. 310. - P. 14-20.

85. Medvedev Z. A. An attempt at a rational classification of theories of ageing // Biol. Rev. Camb. Philos. Soc. - 1990. - Vol. 65 (3). - P. 375-398.

86. Miwa S., Lawiess C., von Zglinicki T. Mitochondrial turnover in liver is fast in vivo sound is accelerated by dietary restriction: application of a simple dynamic model // Aging Cell. - 2008. -Vol. 7 (6). - P. 920-923.

87. Modelling the actions of chaperones and their rake in ageing / Proctor C. J. et al. // Mech. Ageing Dev. 2005. - Vol. 126 (1). - P. 119-131.

88. Mooney K. M., Morgan A. E., Mc Auley M. T. Aging and computational system biology // Wiley Interdiscip. Rev. Syst. Biol. Med. - 2016. - Vol. 8 (2). - P. 123139.

89. Modelling the molecular mechanisms of aging / Mc Auley M. T. et al. // Biosci. Rep. - 2017. - Vol. 37 (1). - P. BSR 20160177.

90. Neel J. V. Diabetes mellitus: a "thrifty" genotype rendered detrimental by "progress”? // Am. J. Hum. Gen. - 1962. - Vol. 14 (4). - P. 353-362.

91. Nesse R. M. Tinbergen's four questions. Two proximate, two evolutionary // Evol. Med. Pub. Health. - 2018. - Vol. 2019 (1). - P. 2.

92. NF-Kb in aging and disease / Tilstra J. S. et al. // Aging Dis. - 2011. - Vol. 2 (6). - P. 449-465.

93. Nuclear DNA damage signaling to mitochondria in ageing / Fang E. F. et al. // Nat. Rev. Mol. Cell Biol. 2016. - Vol. 17 (5). - P. 21-308.

94. Oscillations and variability in the p53 system / Geva-Zatorsky N. et al. // Mol. Syst. Biol. - 2006. Vol. 2. - P. 2006.0033.

95. Pall M. L., Leine S. Nrf 2, a master of detoxification and antioxidant, anti-inflammatory and other cytoprotective mechanisms in raised by health promoting factors // Sheng Li Xue Bao. - 2015. Vol. 67 (1). - P. 1-18. 
96. Pearson C. A., Zeng C., Simba R. Network class superposition analysis // PLoS One. - 2013. - Vol. 8 (4). - P. e59046.

97. Peltonen L., Jalanko A., Varilo T. Molecular genetics of the Finnish disease heritage // Hum. Mol. Genet. 1999. - Vol. 8 (10). - P. 1913-1923.

98. Perkiomaki J. S., Makkikalli T. H., Hyikuri H. V. Fractal and complexity measures of heart rate // Clin. Exp. - 2015. - Vol. 27 (2-3). - P. 149-158.

99. Population history and its impact on medical genetics in Quebec / Laberge A. M. et al. // Clinical Genetics. 2005. - Vol. 68 (4). - P. 287-301.

100. PPARy inhibits inflammatory reaction in oxidative stress induced human diploid fibroblast / Lee Y. H. et al. // Cell. Biochem. Funct. - 2010. - Vol. 28 (6). P. 490-496.

101. Proctor C. J., Kirkwood T. B. Modelling cellular senescence as a result of telomere state // Aging Cell. - 2003. - Vol. 2 (3). - P. 151-157.

102. Proctor C. J., Lorimer I. A. Modelling the role of the Hsp 70/Hsp 90 system in the maintenance of protein homeostasis // PLoS One. - 2011. - Vol. 6 (7). P. e22038.

103. Protein damage, repair and proteolysis / Chondrogiani N. et al. // Mol. Aspects Med. - 2014. - Vol. 35. P. 1-71.

104. Przybilla J., Rohef T., Loeffeer J. Understanding epigenetic changes in aging stem cells - a computational model approach // Aging Cell. 2014. - Vol. 13 (2). - P. 320-328.

105. Ramasamy R., Shekhtman A., Schmidt A. M. The multiple faces of RAGE - opportunities for therapeutic intervention in aging and chronic disease. Expert Opin // Thez. Targets. - 2016. - Vol. 20 (4). P. 431-446.

106. Rattan S. I. Hormesis in aging // Ageing Res. Rev. 2008. - Vol. 7 (1). - P. 63-78.

107. RNA induction and inheritance of epigenetic cardiac hypertrophy in the mouse / Wagner K. D. et al. // Developmental Cell. - 2008. - Vol. 14 (6). - P. 962969.

108. Rubinsztein D. C., Marifio G., Kroemer G. Autophagy and aging // Cell. - 2011. - Vol. 146 (5). - P. 682-695.

109. Regulation of Drosophila lifespan by JNK signaling / Bitean B. et al. // Exp. Gerontol. - 2011. - Vol. 46 (5). - P. 349-354.

110. SBML merge, a system for combining biochemical network models / Schulz M. et al. // Genome Inform. - 2006. - Vol. 17 (1). - P. 62-71.

111. SIRT1 deacetylates the DNA methyltransferase 1 (DNMT1) protein and alters its activities / Peng L. et al. // Mol. Cell Biol. - 2011. - Vol. 31 (23). - P. 4720-4734.

112. SIRT6 promotes DNA repair under stress by activating / Mao Z. et al. // Science. - 2011. - Vol. 332 (6036). P. 1443-1446.
113. Solovyev I. A., Dobrovolskaya E. V., Moskalev A. A. Genetic control of circadian rhythms and aging // Russ. J. Genet. - 2016. - Vol. 52 (4). - P. 343-361.

114. Soltow Q. A., Jones D. P., Promislow D. E. A network perspective on metabolism and aging // Integr. Comp. Biol. - 2010. - Vol. 50 (5). - P. 844-854.

115. Song R., Sarnoski E. A., Acar M. The system biology of single all aging // Science. - 2018. - Vol. 7. P. 157-169.

116. Sosou P. D., Kirkwood T. B. L. A stochastic model of cell replicative senescence based on telomere shortening oxidative stress, a somatic mutation in nuclear and mitochondrial DNA // J. Theor. Biol. 2001. - Vol. 213 (4). - P. 573-586.

117. Swan M. Philosophy of big data. Expanding the human-data relation with big data science services. Режим доступу: https://www.melanieswan.com/ documents/Philosophy_of_Big_Data_SWAN.pdf.

118. System modeling of NHEJ reveals the importance of redox regulation of $\mathrm{Ku} \mathrm{70/80} \mathrm{in} \mathrm{the} \mathrm{dynamics} \mathrm{of} \mathrm{the}$ DNA damage foci / Dolan D. et al. // PLoS One. 2013. - Vol. 8 (2). - P. e55190.

119. Systems modelling ageing: from single senescent cells to simple multi-cellular models / Martinez Guimera A. et al. // Essays Biochem. - 2017. - Vol. 61 (3). P. 369-377.

120. TAF-4 is required for the life extension of isp-1cek-1 and tpk-1 Mit mutants / Khan M. H. et al. // Aging. 2013. - Vol. 5 (10). - P. 741-758.

121. Tan V. P., Miyamoto S. Nutrient sensing mTORC1: integration of metabolic and autophagic signals // J. Mol. Cell Cardiol. - 2016. - Vol. 95. - P. 31-41.

122. Tan Z. Telomere shortening and the population sizedependency of life span of human cell culture // Exp. Gerontol. - 1999. - Vol. 34 (7). - P. 831-842.

123. Targets of balancing selection in the human genome / Andres A. M. et al. // Molecular Biology \& Evolution. - 2009. - Vol. 26 (12). - P. 2755-2764.

124. Telomerase expression confers cardioprotection in the adult mouse heart after acute myocardial infarction / Bar C. et al. // Nat. Commun. - 2014. - Vol. 5. P. 5863.

125. The prospective association between adiponectin and coronary artery disease among individuals with type 1 diabetes /Costacon T. et al. // Diabetology. - 2005. Vol. 48 (1). - P. 41-48.

126. The Ras superfamily of small GTP ases: he unlocked secret / Goitre L. et al. // Meth. Mol. Biol. - 2014. Vol. 1120. - P. 1-18.

127. The GH/IGF-1 axis in ageing and longevity / Junnila R. K. et al. // Nat. Rev. Endocrinol. - 2013. - Vol. 9 (6). - P. 366-376.

128. The relationship between physical fitness and health self-assessment in elderly / Knapik A. et al. // Medicine (Baltimore). - 2019. - Vol. 98 (25). P. e15984. 
129. Van Denrsen J. M. The role of senescent cells in aging // Nature. - 2014. - Vol. 509 (7501). - P. 439-446.

130. Wensink M. J., Wrycza T. F., Bandisch A. No senescence despite declining selection pressure: Hammilton's result in broader perspective // J. Theor. Biol. - 2014. - Vol. 347. - P. 176-181.

\section{References.}

1. Anisimov, V. N. (2003). Molekulyarnye i fiziologicheskie mekhanizmy stareniya [Molecular and physiological mechanisms of aging]. Saint Petersburg: Nauka (Science).

2. Artemov, A. V. \& Buryachkovsky, E. S. (2016). Starenie: razlichiya mezhdu smert'yu kletki i smert'yu organizma s pozitsii matematicheskoi modeli [Distinction between death and organism cells from the positions of the mathematical model]. Ukrainskii zhurnal meditsiny, biologii i sporta (Ukrainian journal of medicine, biology and sport), 3 (1), 215-220. doi: 10.26693/jmbs03.01.215.

3. Voitenko, V.P.(1987). Matematicheskoe modelirovanie v gerontologii [Mathematical modeling in gerontology]. Gerontologiya i geriatriya (Gerontology and Geriatrics): annual. Immunitet i starenie (Immunity and Aging). Digest. Kyiv, P. 118-130.

4. Voropaeva, E. F., Shokin, Yu. N., Nepomnyashchikh, L. M., \& Senchukova, S. R. (2014). Matematicheskoe modelirovanie funktsionirovaniya sistemy belkov p53-MDM2 [Mathematical modeling of functioning of the p53-Mdm2 protein system]. Byulleten' ehksperimental'noi biologii i meditsiny (Bull. Exp. Biol. Med.), 157 (2), 291-294. doi: 10.1007/s10517-014-2548-3.

5. Galitskii, V. A. (2009). Ehpigeneticheskaya priroda stareniya [The epigenetic nature of aging]. Tsitologiya (Cytology), 51 (2), 388-397.

6. Gerasimenko, N. D., Degtyar', N. I., Rasin, M. S. (2016). Sistemnoe vospalenie i starenie: rol'yadernykh transkriptsionnykh faktorov terapevticheskoi vozmozhnosti [Systemic inflammation and aging: the role of nuclear transcription factors in therapeutic potential]. Problemy stareniya i dolgoletiya (Aging and Longevity), 25 (4), 554-561.

7. Dontsov, V. I. (2006). Metodologiya sushchnostnogo modelirovaniya stareniya i ryad modelei, postroennykh s ee pomoshch'yu [Essential aging modeling methodology and a number of models built with its help]. Trudy ISA RAN (Proceedings of ISA RAS), 19, 94-116.

8. Krut'ko, V. M., Dontsov, V. I. (2008). Sistemnye mekhanizmy i modeli stareniya [Systemic mechanisms and aging patterns]. Moscow, URSS Rgess.
131. West G. B., Bergman A. Toward a system biology framework for understanding aging and health span // J. Gerontol. A. Biol. Sci. Med. Sci. - 2009. Vol. 64 (2). - P. 205-208.

132. Williams G. C., Nesse R. M. The dawn of Darwinian medicine // Q. Rev Biol. - 1991. - Vol. 66 (1). P. 1-22.

9. Mintser, O. P., Zaliskyi, V. M. (2019). Systemna biomedytsyna [Systemic biomedicine]. Vol. 1. Kyiv, Interservis.

10. Mikheev, A. N. (2014). Problemy teorii biologicheskoi ehvolyutsii (Prolegomeny ehvolyutsionistiki) [Problems of the theory of biological evolution (Prolegomena of evolutionism)]. Kyiv, Fitotsentr (Phytocenter).

11. Novosel'tsev, V. N., Novosel'tseva, Zh. A., Iashin, I. (2003). Matematicheskoe modelirovanie v gerontologii — strategicheskie perspektivy [Mathematical modeling in gerontology - strategic perspectives]. Uspekhi gerontologii (Advances in Gerontology), 12, 149-165.

12. Khalyavkin, A. V., Krut'ko, V. M. (2006). Podkhod k modelirovaniyu stareniya s pozitsii biofiziki slozhnykh system [An approach to modeling aging from the standpoint of biophysics of complex systems]. Trudy ISA RAN (Proceedings of ISA RAS), 19, 117-155.

13. AAMC-HHMI. Scientific Foundation for Future Physicians Committee. Scientific Foundations for Future Physicians. Washington, DC: American Association of Medical Colleges and Howard Hughes Medical Institute; 2009.

14. Proctor, C. J., Macdonald, C., Milner, J. M., Rowan, A, D., \& Cawston, T. E. (2014). A computer simulation approach to assessing therapeutic intervention points for the prevention of cytokine-induced cartilage breakdown. Arthritis Rheumatol., 66 (4), 979-989. doi: 10.1002/art.38297.

15. Picca, A., Pesce, V., Fracasso, F., Joseph, A.-M., Leeuwenburgh, C., \& Lezza, A. M. S. (2013). Aging and calorie restriction oppositely affect mitochondrial biogenesis through TFAM binding at both origins of mitochondrial DNA replication in rat liver. PLOS ONE, 8 (9), e74644. doi: 10.1371/journal.pone.0074644.

16. Sighania, R., Sramkoski, R. M., Jacobberger, J. W.. \& Tyson, J. J. (2011). A hybrid model of mammalian cell cycle regulation. PLoS Comput. Biol., 7 (2), e1001077. doi: 10.1371/journal.pcbi.1001077.

17. Akey, J. M. (2009). Constructing genomic maps of positive selection in humans: where do we go from here? Genome Res., 19 (5), 711-722. doi: 10.1101/ gr.086652.108. 
18. Curtius, K., Wong, C.,J., Hazelton, W. B., Kaz, A. M., Chak, A., Willis, J. E. ... Luebeck, E. G. (2016). A molecular clock inters heterogeneous tissue age accusing patients with Barrett's esophagus. Plos. One, 12 (5), e1004919. doi: 10.1371/journal.pcbi.1004919.

19. A new vision for old age. Rethinking health policy for Europe's ageing society. A report from the Economist Intelligence Unit // The Economist Intelligence Unit Limited. 2012. 4. https://www.learneurope.eu/ files/5613/7525/7796/Repensando_la_poltica_de_ salud_sociedad_europea_envejecida.pdf.

20. Gauthier, L. D., Greenstein, J. L., O’Rourke, B., \& Winslow, R. L. (2013). An integrated mitochondrial ROS production and scavenging model: implications for heart failure. Biophys. J., 105 (12), 2832-2842. doi: 10.1016/j.bpj.2013.11.007.

21. Krause, F., Ulendorf, J., Lubitz, T., Schulz, M., Klipp, E., \& Liebermeister, W. (2010). Annotation and merging of SBML models with semantic SBML. Bioinformatics, 26 (3), 421-428. doi: 10.1093/ bioinformatics/btp642.

22. Aschner, Y. \& Downey, G. P. (2016). Transforming growth factor- $\beta$ : master regulator of the respiratory system in health and disease. Am. J. Respir. Cell Mol. Biol., 54 (5), 55-647. doi: 10.1165/rcmb.20150391TR.

23. Vagetti, G. C., Barbosa Filho, V. C., Moreira, N. B., de Oliveira, V., Mazzardo, O., de Campos W. (2014). Association between physical activity and quality of life in the elderly: a systematic review, 2000-2012. Rev. Bras. Psiquiatr., 36 (1), 76-88. doi: 10.1590/1516-4446-2012-089.5.

24. Govindarajn, D. R., Pencina, K. M., Raj, D. S., Massaro, J. M., Carnes, B. A., D’Agostino, R. B. (2014). A system analysis of age-related changes in some cardiac aging traits. Biogerontology, 15 (2), 139-152. doi: 10.1007/s10522-013-9486-8.

25. Barja, G. (2014). The mitochondrial free radical theory of aging. Prog. Mol. Biol. Transl. Sci., 127, 1-27. doi: 10.1016/B978-0-12-394625-6.00001-5.

26. Barreiro, L. B. \& Quintana-Murci, L. (2010). From evolutionary genetics to human immunology: how selection shapes host defense genes. Nat. Rev. Genet., 11 (1), 17-30. doi: 10.1038/nrg2698.

27. Bitto, A., Wang, A. M., Bennett, C. F., \& Kaeberlein, M. (2015). Biochemical genetic pathways that modulate aging in multiple species. Cold Harbor Persp. Med., 5 (11), a025114. doi: 10.1101/ cshperspect.a025114.

28. Chelliah, V., Juty, N., Ajmera, J., Ali, R., Dumousseau, M., Glont, M. ... Laibe, C. (2015). BioModels: tenyear anniversary. Nucleic Acids Res., 43, D542-D548. doi: 10.1093/nar/gku1181.

29. Cvijovic, M., Almquist, A. J., Hagmar, J., Hohmann, S., Kaltenbach, H.-M., Klipp, E. ... Jirstrand, M. (2014). Bridging the gaps in system biology. Mol. Genet. Genomics, 289 (5), 727-734. doi: 10.1007/ s00438-014-0843-3.
30. Sutterlin, T., Kolb, C., Dickhaus, H., Jäger, D.. \& Grabe, N. (2013). Bridging the scale: semantic integration of quantitable SBML in graphical multicellular models and simulation with EPISM and COPASI. Bioinformatics, 29 (2), 223-229. doi: 10.1093/bioinformatics/bts659.

31. Budanov, A. V. \& Karin, M. (2008). p53 target genes sestrin 1 and sestrin 2 connect genotoxic stress and mTOR signaling. Cell, 134 (3), 451-460. doi: 10.1016/j.cell.2008.06.028.

32. Carrol, B., Hewitt, G., \& Korolchuk, V. I. (2013). Autophagy and ageing: implications for age-related neurodegenerative diseases. Essays Biochem., 55, 119-131. doi: 10.1042/bse0550119.

33. Cheong, J. K., Zhang, F., Chua P. J., Bay, B. H., Thorburn, A., \& Virshup, D. M. (2015). Casein kinase $1 \alpha$-dependent feedback loop controls autophagy in RAS-driven cancer. J. Clin. Invest., 125 (4), 14011418. doi: 10.1172/JCI78018.

34. Chen, D. \& Guarente, L. (2007). SIR 2: a potential target for calorie restriction mimetics. Trends. Mol. Med., 13 (2), 64-71. doi: 10.1016/j.molmed.2006.12.004.

35. Tishkoff, S. A., Reed, F. A., Ranciaro, A., Voight, B. F., Babbitt, C. C., Silverman, J. S., ... Deloukas, P. (2007). Convergent adaptation of human lactase persistence in Africa and Europe. Nature Genetics, 39 (1), 31-40. doi: 10.1038/ng1946.

36. Grunspan D. Z., Nesse R. M., Barnes M. E., \& Brownell, S. E. (2017). Core principles of evolutionary medicine: A Delphi study. Evol. Med. Public Health, 2018 (1), 13-23. doi: 10.1093/emph/eox025.

37. Corpet, A. \& Stucki, M. (2014). Chromatin maintenance and dynamics in senescence: a spotlight on SAHF formation and the epigenome of senescent cells. Chromosoma, 123 (5), 423-436. doi: 10.1007/ s00412-014-0469-6.

38. Cybulski, M., Krajewska-Kulak, E., \& Jamiolkowski, J. (2015). Preferred health behaviors and quality of life of the elderly people in Poland. Clin. Interv. Aging, 10, 1555-1564. doi: 10.2147/CIA.S92650.

39. Crespi, B. J. (2010). The emergence of humanevolutionary medical genomics. Evolutionary Applications, 4 (2), 292-314. doi: 10.1111/j.17524571.2010.00156.

40. Tomaru, U., Takahashi, S., Ishiru, A. Miyatake, Y., Gohda, A., Suzuki, S. ... Kasahara, M. (2012). Decreased proteasomal activity causes age-related phenotypes and promotes the development of metabolic abnormalities. Am. J. Pathol., 180 (3), 963-972. doi: 10.1016/j.ajpath.2011.11.012.

41. Cohen, A. A., Milot, E., Li, Q., Bergeron, P., Poirier, R., Dusseault-Bélanger, F. ... Ferrucci, L. (2015). Detection of a novel, integrative aging process suggest complex physiological integration. PLoS One, 10 (3), e0116489. doi: 10.1371/journal.pone.0116489.

42. Dinsdale, N., Nepomnaschy, P., \& Crespi, B. (2021). The evolutionary biology of endometriosis. Evol. Med Pub. Health, 9 (1), 174-191. doi: 10.1093/emph/ eoab008. 
43. Maslov, A. Y., Ganapathi, S., Westerhof, M., QuispeTintaya, W., White, R. R., Van Houten, B. ... Vijg, J. (2013). DNA damage innormally and prematurely aged mice. Aging Cell, 12 (3), 467-477. doi: 10.1111/ acel.12071.

44. Murray, P. J., Cornelissen, B., Vallis, K. A., \& Chapman, S. J. (2016). DNA double-strand break repair: a theoretical framework and its applications. J. R. Soc. Interfase, 13 (114), 20150679. doi: 10.1098/ rsif.2015.0679.

45. Dalle Pezze, P., Nelson, G., Otten, E. G., Korolchuk, V. I., Kirkwood, T. B. L., von Zglinicki, T., \& Shanley, D. P. (2014). Dynamic modeling of pathways to cellular senescence reveals strategies for targeted intervention. PloS. Comput. Biol., 10 (8), e1003728.

46. Tavassoly, I., Parmar, J., Shajahan-Hag, A. N., Clarke, R., Baumann, W. T.. \& Tyson, J. J. (2015). Dynamic modeling of the interaction between autophagy and apoptosis in mammalian cells. CPT Pharmacometrics Drug Pharmacol., 4 (4), 263-272. doi: 10.1002/ psp4.29.

47. Efeyan, A., Zoncu, R., \& Sabatini, D. H. (2016). Amino acids and mTORC1: from lysosomes to disease. Trends Mol. Cell Biol., 18 (9), 33-524. doi: 10.1016/j. molmed.2012.05.007.

48. Hoftman J. M., Soltow Q. A., Li S., Sidik, A., Jones, D. P., Promislow, D. E. L. (2014). Effects of age, sex, and genotype on gene-sensitivity metabolomic profiles in the bruit fry, Drosophila melanogaster. Aging Cell., 13 (4), 596-604. doi: 10.1111/acel.12215.

49. Eurostat Statistics Explained. Available at: http:// ec.europa.eu/eurostat/statistics-explained/index.php/ Fertility_statistics\#Main_statistical_findings.

50. Passos, J. F., Nelson, G., Wang, C., Richter, T., Simillion, C., Proctor, C. J. ... von Zglinicki T. (2010). Feedback between p21 and reactive oxygen production is necessary for cell senescence. Mol. Syst. Biol., 6, 347. doi: 10.1038/msb.2010.5.

51. Fogel, R. W. The escape from hunger and premature death, 1700-2100: Europe, America and the Third World. Cambridge: Cambridge University Press; 2004.

52. Crider K. S., Yang T. P., Berry R. J., \& Bailey, L. B. (2012). Folate and DNA methylation: a review of molecular mechanism and the evidence for folates role. Adv. Nutr., 3 (1), 21-38. doi: 10.3945/ an.111.000992.

53. Garcia-Martinez, J. M. \& Alessi, D. R. (2008). mTOR complex 2 (mTORC2) controls hydrophobic motif phosphorylation and activation of serum and glucocorticoid-induced protein kinase 1 (SGK 1). Biochem J., 416 (3), 375-385. doi: 10.1042/ BJ20081668.

54. Halverson M. S. \& Bolnick D. A. (2008). An ancient DNA test of a founder effect in Native American ABO blood group frequencies. Am. J. Phys. Anthropol., 137 (3), 342-347. doi: 10.1002/ajpa.20887.
55. Mendias, C. L., Bakhurin, K. I., Gumucio, J. P., Shallal-Ayzin, M. V., Davis, C. S., \& Faulkner, J. A. (2015). Haploinsufficiency of myostatin protects against aging-related declines in muscle function and enhances. Aging Cell., 14 (4), 704-706. doi: 10.1111/ acel.12339.

56. Herskovitz A. Z. \& Guarente L. (2014). SIRT1 in neurodevelopment and brain senescence. Neuron, 81 (3), 471-483. doi: 10.1016/j.neuron.2014.01.028.

57. Hill S. M., Hanzen S., \& Nystrom T. (2017). Restricted access: spatial sequestration of damage proteins during stress and aging. EMBO Rep., 18 (3), 377-391. doi: 10.15252/embr.201643458.

58. Gluckman, P. D., Low, F. M., Buklijas, T., Hanson, M. A., \& Beedle, A. S. (2011). How evolutionary principles improve the understanding of human health and disease. Evol. Appl., 4 (2), 249-263. doi:10.1111/j.1752-4571. 2010.00164.

59. Brannmark, C., Nyman, E., Fagerholm, S., Bergenholm, L., Ekstrand, E.-M., Cedersund, G., \& Strålfors, P. (2013). Insulin signaling in type 2 diabetes: experimental and modeling analyses reveal mechanisms of insulin resistance in human adipocytes. J. Biol. Chem., 288 (14), 9867-9880. doi: 10.1074/ jbc.M112.432062.

60. Dolan, D., Zupanic, A., Nelson, G., Hall, P., Miwa, S., Kirkwood, T. B. L., \& Shanley, D. P. (2015). Integrated stochastic model of DNA damage repair by Non-homologous end joining and p53/p21-mediated early senescence signaling. PloS Compat. Biol., 11 (5), e1004246. doi: 10.1371/journal.pcbi.1004246.

61. Jablonka E. \& Raz G. (2009). Transgenerational epigenetic inheritance: prevalence, mechanisms, and implications for the study of heredity and evolution. Quart. Rev. Biol., 84 (2), 131-176. doi: 10.1086/598822.

62. Kaplan, H. S. \& Robson, A. J. (2009). We age because we grow. Proceedings of the Royal Society BBiological Sciences, 276 (1663), 1837-1844. doi: 10.1098/rspb.2008.1831.

63. Keywords and concepts in evolutionary developmental biology. Eds: Hall, B, K. \& Olson, W. M. New Delhi, India: Discovery Publishing House, 2007.

64. Kirkwood, T. B. (1977). Evolution of ageing. Nature, 270, 301-304.

65. Kirkwood, T. B. (2011). Systems biology of ageing and longevity. Philos. Trans. R. So. Lond. B. Biol. Sci., 366 (1561), 64-70. doi: 10.1098/rstb.2010.0275.

66. Kirkwood, T. B. (2005). Understanding the odd science of aging. Cell, 120 (4), 437-447. doi: 10.1016/j. cell.2005.01.027.

67. Kirkwood, T. B. L., Proctor, C. J. (2003). Somatic mutations and ageing in silico. Mech. Ageing Dev., 124 (1), 85-92. doi: 10.1016/s0047-6374(02)00177-x. 
68. Kirkwood, T. B. L. (2017). Why and how are we living longer? Exp. Physiol., 102 (9), 1067-1074. doi: 10.1113/EP086205.

69. Kitano, H. (2007). Towards a theory of biological robustness. Mol. Syst. Biol., 3, 137. doi: 10.1038/ msb4100179.

70. Goetz, R., Ohnishi, M., Ding, X., Kurosu, H., Wang, L., Akiyoshi, J. ... Mohammadi, M. (2012). Klotho co receptors inhibit signaling by paracrine fibroblast growth factor 8 subfamily ligands. Mol. Cell. Biol., 32 (10), 1944-1954. doi: 10.1128/MCB.06603-11.

71. Kowald, A., \& Kirkwood, T. B. (2000). Accumulation of defective mitochondria through delayed degradation of damaged organelles and its possible role in the ageing of post-mitotic and dividing cells. J. Theor. Biol., 202 (2), 145-160. doi: 10.1006/jtbi.1999.1046.

72. Kowald, A., Kirkwood, T. B. (1996). A network theory of aging: the interactions of defective mitochondria, aberrant proteins, free radicals and scavengers in the aging process. Mutat. Res., 316 (5-6), 209-236. doi: 10.1016/s0921-8734(96)90005-3.

73. Kowald, A., \& Klipp, E. (2014). Mathematical models of mitochondrial aging and dynamics. Prog. Mol. Biol. Transl. Sci., 127, 63-92. doi: 10.1016/B978-012-394625-6.00003-9.

74. Kriete, A., Bost, W. J., \& Booker, G. (2010). Rulebased cell systems model of aging using feedback loop motifs mediated by stress responses. PLoS Comput. Biol., 6 (6), e1000820. doi: 10.1371/journal. pcbi.1000820.

75. Kriete, A. (2013). Robustness and aging — a systems level perspective. Biosystems, 112 (1), 37-48. doi: 10.1016/j.biosystems.2013.03.014.

76. Labbadia, J., \& Morimoto, R. I. (2015). The biology of proteostasis in aging and disease. Annu Rev. Biochem., 84, 435-464. doi: 10.1146/annurevbiochem-060614-033955.

77. Laland, K. N., Odling-Smee, J., \& Myles, S. (2010). How culture shaped the human genome: bringing genetics and the human sciences together. Nat. Rev. Genet., 11, 137-148.

78. Lai, X., Wolkenhauer, O., \& Vera, J. (2012). Modeling miRNA regulation in cancer signaling system: miR$34 \alpha$ regulation of the $\mathrm{p} 53 /$ Sirt1 signaling module. Methods Mol. Biol., 880, 87-108. doi: 10.1007/9781-61779-833-7_6.

79. Lai, X., Wolkenhauer, O., \& Vera, J. (2016). Understanding microRNA-mediated gene regulatory networks through mathematical modeling. Nucleic Acids Res., 44 (13), 6019-6035. doi: 10.1093/nar/ gkw550.

80. Lee, R. D. (2003). Rethinking the evolutionary theory of aging: Transfers, not births, shape senescence in social species. PNAS, 100 (16), 9637-9642. doi: 10.1073/ pnas. 1530303100.
81. Somogyi, E. T., Bouteiller, J. M., Glazier, J. A., König, M., Medley, J. K., Swat, M. H.. \& Sauro, H. M. (2015). libRoadRunner: a high performance SBML simulation and analysis library. Bioinformatics, 31 (20), 33153321. doi: 10.1093/bioinformatics/btv363.

82. Lipsitz, L. A., \& Goldberger, A. L. (1992). Loss of 'complexity' and aging. Potential applications of fractals and chaos theory to senescence. JAMA, 267 (13), 1806-1809.

83. Marin-Garcia, J. (2016). Mitochondrial DNA repair: a novel therapeutic target for heart failure. Heart Fail. Rev., 21 (5), 87-475. doi: 10.1007/s10741-016-9543-X.

84. Mc Govern A. P., Powell B. E., \& Chevassut T. J. (2012). A dynamic multi-compartmental model of DNA methylation with demonstrable predictive value in hematological malignancies. J. Theor. Biol., 310, 14-20. doi: 10.1016/j.jtbi.2012.06.018.

85. Medvedev, Z. A. (1990). An attempt at a rational classification of theories of ageing. Biol. Rev. Camb. Philos. Soc., 65 (3), 375-398. doi: 10.1111/j.1469185x.1990.tb01428.x.

86. Miwa, S., Lawiess, C., \& von Zglinicki T. (2008). Mitochondrial turnover in liver is fast in vivo sound is accelerated by dietary restriction: application of a simple dynamic model. Aging Cell., 7 (6), 920-923. doi: 10.1111/j.1474-9726.2008.00426.

87. Proctor, C. J., Sotiv, C., Boys, R. J., Gillespie, C. S., Shanley, D. P., Wilkinson, D. J., \& Kirkwood, T. B. L. (2005). Modelling the actions of chaperones and their rake in ageing. Mech. Ageing Dev., 126 (1), 119-131. doi: 10.1016/j.mad.2004.09.031.

88. Mooney, K. M., Morgan, A. E., \& Mc Auley, M. T. (2016). Aging and computational system biology. Wiley Interdiscip. Rev. Syst. Biol. Med., 8 (2), 123-139. doi: 10.1002/wsbm.1328.

89. Mc Auley, M. T., Martinez Guimere, A., Hodson, D., Mcdonald, N., Mooney, K. M., Morgan, A. E., \& Proctor, C. J. (2017). Modelling the molecular mechanisms of aging. Biosci. Rep., 37 (1), BSR 20160177. doi: 10.1042/BSR20160177.

90. Neel, J. V. (1962). Diabetes mellitus: a “thrifty” genotype rendered detrimental by "progress"? Am. J. Hum. Genet., 14 (4), 353-362.

91. Nesse, R. M. (2018). Tinbergen's four questions. Two proximate, two evolutionary. Evol. Med. Pub. Health, 2019 (1), 2 doi:10.1093/emph/eoy035.

92. Tilstra, J. S., Tilstra, J. S., Clanson, C. L., Niedernhofer, L. J.. \& Robbins, P. D. (2011). NF-Kb in aging and disease. Aging Dis., 2 (6), 449-465.

93. Fang, E. F., Scheibye-Knudsen, M., Chua, K. F., Mattson, M. P., Croteau, D. L., \& Bohr, V. A. (2016). Nuclear DNA damage signaling to mitochondria in ageing. Nat. Rev. Mol. Cell Biol., 17 (5), 308-321. doi: 10.1038/nrm.2016.14. 
94. Geva-Zatorsky, N., Rosenfeld, N., Itzkovitz, S., Milo, R., Sigal, A., Dekel, E., ... Alon, U. (2006). Oscillations and variability in the p53 system. Mol. Syst. Biol., 2, 2006.0033. doi: 10.1038/msb4100068.

95. Pall, M. L., \& Leine, S. (2015). Nrf 2, a master of detoxification and antioxidant, anti-inflammatory and other cytoprotective mechanisms in raised by health promoting factors. Sheng Li Xue Bao, 67 (1), 1-18.

96. Pearson, C. A. B., Zeng, C., \& Simha, R. (2013). Network class superposition analysis. PLoS One, 8 (4), e59046. doi:10.1371/journal.pone.0059046.

97. Peltonen, L., Jalanko, A., \& Varilo, T. (1999). Molecular genetics of the Finnish disease heritage. Human Molecular Genetics, 8 (10), 1913-1923. doi: 10.1093/ hmg/8.10.1913.

98. Perkiomaki, J. S., Makkikallio, T. H., \& Hyikuri, H. V. (2015). Fractal and complexity measures of heart rate. Clin. Exp., 27 (2-3), 149-158.

99. Laberge, A. M., Michaud, J., Richter, A., Lemyre, E., Lambert, M., Brais, B., Mitchell, G. A. (2005). Population history and its impact on medical genetics in Quebec. Clinical Genetics, 68 (4), 287-301. doi: 10.1111/j.1399-0004.2005.00497.

100. Lee, Y. H., Lee, N. H., Bhattarai, G., Yun, J.-S., Kim, T.-I., Jhee, E.-C., Yi, H.-K. (2010). PPARy inhibits inflammatory reaction in oxidative stress induced human diploid fibroblast. Cell. Biochem. Funct., 28 (6), 490-496. doi: 10.1002/cbf.1681.

101. Proctor, C. J., \& Kirkwood, T. B. (2003). Modelling cellular senescence as a result of telomere state. Aging Cell, 2 (3), 151-157. doi: 10.1046/j.14749728.2003.00050.

102. Proctor, C. J., \& Lorimer, I. A. (2011). Modelling the role of the Hsp 70/Hsp 90 system in the maintenance of protein homeostasis. PLoS One., 6 (7), e22038. doi: 10.1371/journal.pone.0022038.

103. Chondrogianni, N., Petropoulos, I., Grimm, S. Georgila, K., Catalgol, B., Friguet, B. ... Gonos, E. S. (2014). Protein damage, repair and proteolysis. Mol. Aspects Med., 35, 1-71. doi: 10.1016/j.mam.2012.09.001.

104. Przybilla, J., Rohef, T., Loeffeer, J.. \& Galle, J. (2014). Understanding epigenetic changes in aging stem cells - a computational model approach. Aging Cell., 13 (2), 320-328. doi: 10.1111/acel.12177.

105. Ramasamy, R., Shekhtman, A.. \& Schmid,t A. M. (2016). The multiple faces of RAGE — opportunities for therapeutic intervention in aging and chronic disease. Expert Opin. Ther. Targets, 20 (4), 431-446. doi: 10.1517/14728222.2016.1111873.

106. Rattan, S. I. (2008). Hormesis in aging. Ageing Res. Rev., 7 (1), 63-78. doi: 10.1016/j.arr.2007.03.002.

107. Wagner, K. D., Wagner, N., Ghanbarian, H., Grandjean, V., Gounon, P., Cuzin, F.. \& Rassoulzadegan, M. (2008). RNA induction and inheritance of epigenetic cardiac hypertrophy in the mouse. Developmental Cell, 14 (6), 962-969. doi: 10.1016/j.devcel.2008.03.009.
108. Rubinsztein, D. C., Marifio, G.. \& Kroemer, G. (2011). Autophagy and aging. Cell, 146 (5), 682-695. doi: 10.1016/j.cell.2011.07.030.

109. Biteau, B., Karpas, J., Hwangbo, D., \& Jasper, H. (2011). Regulation of Drosophila lifespan by JNK signaling. Exp. Gerontol., 46 (5), 349-354. doi: 10.1016/j.exger.2010.11.003.

110. Schulz, M., Uhlendorf, J., Klipp, E.. \& Liebermeister, W. (2006). SBMLmerge, a system for combining biochemical network models. Genome Inform., 17 (1), 62-71.

111. Peng, L., Yuan, Z., Ling, H., Fukasawa, K., Robertson, K., Olashaw, N. ... Seto, E. (2011). SIRT1 deacetylates the DNA methyltransferase 1 (DNMT1) protein and alters its activities. Mol. Cell Biol., 31 (23), 47204734.

112. Mao, Z., Hine, C., Tian, X., Van Meter, M., Au, M., Vaidya, A., ... Gorbunova, V. (2011). SIRT6 promotes DNA repair under stress by activating. Science, 332 (6036), 1443-1446. doi: 10.1126/science.1202723.

113. Solovyeva, I. A., Dobrovolskaya, E. V.. \& Moskalev, A. A. (2016). Genetic control of circadian rhythms and aging. Russ. J. Genet., 52 (4), 343-361.

114. Soltow, Q. A., Jones, D. P.. \& Promislow, D. E. (2010). A network perspective on metabolism and aging. Integr. Comp. Biol., 50 (5), 844-854. doi: 10.1093/ icb/icq094.

115. Song, R., Sarnoski, E. A.. \& Acar, M. (2018). The system biology of single all aging. Science, 7, 157169. doi: 10.1016/j.isci.2018.08.023.

116. Sosou, P. D.. \& Kirkwood, T. B. L. (2001). A stochastic model of cell replicative senescence based on telomere shortening oxidative stress, a somatic mutation in nuclear and mitochondrial DNA. J. Theor. Biol., 213 (4), 573-586. doi: 10.1006/jtbi.2001.2432.

117. Swan, M. Philosophy of big data. Expanding the human-data relation with big data science services. https://www.melanieswan.com/documents/ Philosophy_of_Big_Data_SWAN.pdf.

118. Dolan D., Melson G., Zupanic A., Smith, G., \& Shanley, D. (2013). System modeling of NHEJ reveals the importance of redox regulation of $\mathrm{Ku} \mathrm{70/80} \mathrm{in} \mathrm{the}$ dynamics of the DNA damage foci. PLoS One, 8 (2), e55190. doi: 10.1371/journal.pone.0055190.

119. Martinez Guimera, A., Welsh, C., Dalle Pezze, P. Fullard, N., Nelson, G., Roger, M. F. ... Shanley, D. P. (2017). Systems modelling ageing: from single senescent cells to simple multi-cellular models. Essays Biochem., 61 (3), 369-377. doi: 10.1042/ EBC20160087.

120. Khan, M. H., Ligon, M., Hussey, L. R., Hufnal, B., Farber, R. 2nd, Munkácsy, E. ... Rea, S. L. (2013). TAF-4 is required for the life extension of isp-1cek-1 and tpk-1 Mit mutants. Aging, 5 (10), 741-758. doi: 10.18632/aging.100604. 
121. Tan, V. P.. \& Miyamoto, S. (2016). Nutrient sensing mTORC1: integration of metabolic and autophagic signals. J. Mol. Cell Cardiol., 95, 31-41. doi: 10.1016/j.yjmcc.2016.01.005.

122. Tan, Z. (1999). Telomere shortening and the population size-dependency of life span of human cell culture. Exp. Gerontol., 34 (7), 831-842. doi: 10.1016/s05315565(99)00056-X.

123. Andres, A. M., Hubisz, M. J., Indap, A., Torgerson, D. G., Degenhardt, J. D., Boyko, A. R. ... Nielsen, R. (2009). Targets of balancing selection in the human genome. Molecular Biology \& Evolution, 26 (12), 2755-2764. doi: 10.1093/molbev/msp190.

124. Bar, C., Bernardes de Jesus, B., Serrano, R., Tejera, A., Ayuso, E., Jimenez, V. ... Blasco, M. A. (2014). Telomerase expression confers cardioprotection in the adult mouse heart after acute myocardial infarction. Nat. Commun., 5, 5863. doi: 10.1038/ncomms6863.

125. Costacou, T., Zgibor, J. C., Evans, R. W., Otvos, J., Lopes-Virella, M. F., Tracy, R. P., \& Orchard, T. J. (2005). The prospective association between adiponectin and coronary artery disease among individuals with type 1 diabetes. The Pittsburgh Epidemiology of Diabetes Complications Study. Diabetologia, 48 (1), 41-48. doi: 10.1007/s00125004-1597-y.
126. Goitre, L., Trapani, E., Trabalzini, L., Retta, S. F. (2014). The Ras superfamily of small GTPases: the unlocked secret. Meth. Mol. Biol., 1120, 1-18. doi: 10.1007/978-1-62703-791-4_1.

127. Junnila R. K., List E. O., Berryman D. E. Murrey, J. W., \& Kopchick, J. J. (2013). The GH/IGF-1 axis in ageing and longevity. Nat. Rev. Endocrinol., 9 (6), 366-376. doi: 10.1038/nrendo.2013.67.

128. Knapik A., Brzęk A., Famuła-Wąż A., Gallert-Kopyto, W., Szydłak, D., Marcisz, C., \& Plinta R. (2019). The relationship between physical fitness and health self-assessment in elderly. Medicine (Baltimore), 98 (25), e15984. doi:10.1097/MD.0000000000015984.

129. Van Deursen, J. M. (2014). The role of senescent cells in aging. Nature, 509 (7501), 439-446.

130. Wensink, M. J., Wrycza, T. F.. \& Bandisch, A. (2014). No senescence despite declining selection pressure: Hammilton's result in broader perspective. J. Theor. Biol., 347, 176-181. doi: 10.1016/j.jtbi.2013.11.016.

131. West, G. B.. \& Bergman, A. (2009). Toward a system biology framework for understanding aging and health span. J. Gerontol. A. Biol. Sci. Med. Sci., 64 (2), 205208. doi: 10.1093/gerona/gln066.

132. Williams, G. C. \& Nesse, R. M. (1991). The dawn of Darwinian medicine. Q. Rev Biol., 66 (1), 1-22. doi: 10.1086/417048. 